\title{
Prospects of cash crop production in CBSR of Russia
}

\author{
Dissertation \\ to obtain the Ph. D. degree \\ in the International Ph. D. Program for Agricultural Sciences in Goettingen \\ (IPAG) \\ at the Faculty of Agricultural Sciences, \\ Georg-August-University Göttingen, Germany
}

\author{
presented by \\ Chetvertakov Sergey \\ born in Voronezh, USSR
}

Göttingen, June 2017 
1. Name of supervisor: Prof. Dr. Folkhard Isermeyer

2. Name of co-supervisor: Prof. Dr. Ludwig Theuvsen

Date of dissertation: June 26, 2017 


\section{Table of Contents}

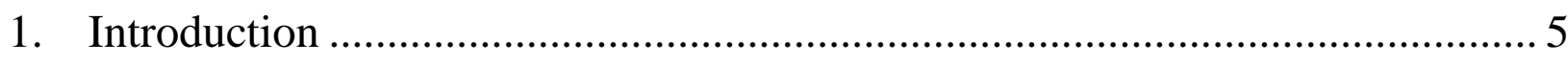

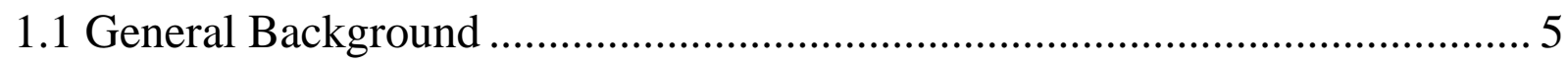

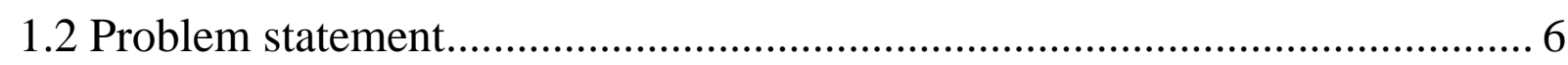

1.3 Structure and following chapters .............................................................. 7

2. Corn and soy in Russia: the latest fad or a new cash cow?............................... 14

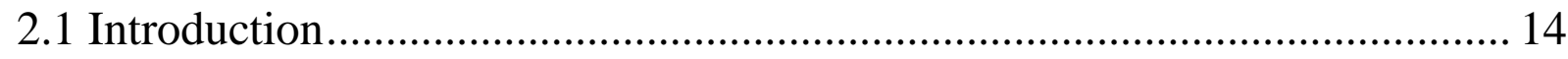

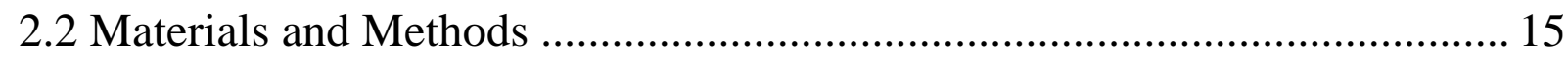

2.3 Economics and farming conditions of major CBSR arable crops ................. 16

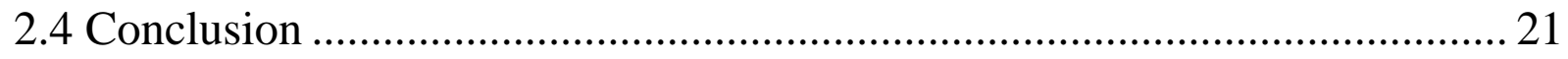

3. Corn and Soybeans in the Central Black Soil Region of Russia: A fundamental shift in cropping patterns ahead of us? ................................................................... 23

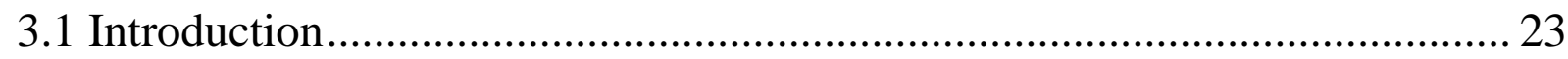

3.2 Evolution Of Cropping Patterns In Russia And The CBSR............................ 24

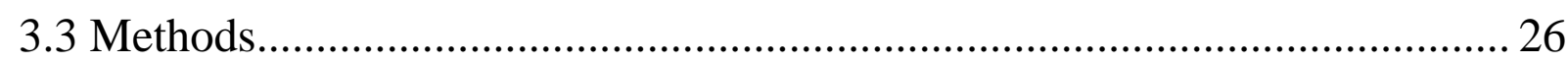

3.4 Economics And Farming Conditions Of The Major CBSR Arable Crops ... 28

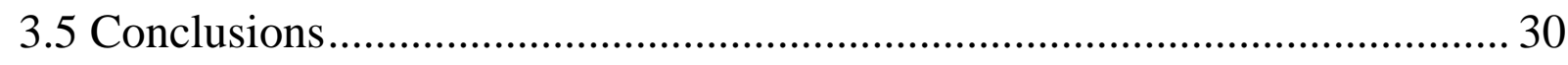

4. Crop choice decision under uncertainty: a case study in Russia ......................... 32

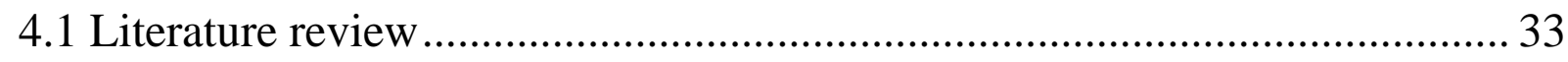

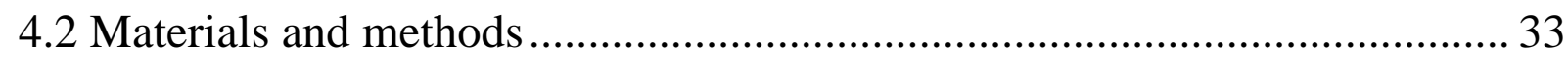

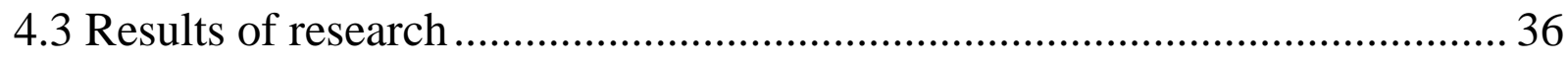

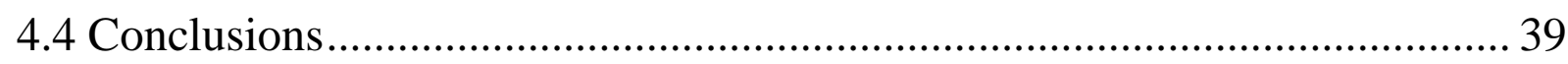

5. Welfare Analysis of Lifting the GM Ban in Russia............................................. 42 
5.1 Introduction. 42

5.2 Materials and methods. 43

5.3 Results and discussion 45

5.4 Conclusion 47

6. Summary of Findings and Conclusions 50

6.1 Corn and soy in Russia: the latest fad or a new cash cow? 50

6.2 Corn and Soybeans in the Central Black Soil Region of Russia: A fundamental shift in cropping patterns ahead of us? 52

6.3 Crop choice decision under uncertainty: a case study in Russia. 54 6.4 Welfare analysis of lifting the GM ban in Russia 56 


\section{Introduction}

\subsection{General Background}

A radical change in Russia's political and economic systems in the early 1990s led to the legalization of private property and market economy. It significantly changed the national economy including the agricultural sector. Russian domestic market's involvement in the global market has significantly changed the market conditions and the profitability from different crops (Liefert \& Liefert, 2012). The most interesting and rapidly growing crops have been corn and soybeans, both of which previously had a small share in the structure of sown areas.

Statistically speaking, Russian crop production reflects a significant rise in the cultivation of corn and soybeans: the acreage of these two crops increased by $10.2 \%$ every year from 2000 to 2013 . One of the highest growth rates, along with a significant share in the national output, can be found in the Central Black Soil Region (CBSR): corn acreage increased by $17.3 \%$ annually and soya beans acreage by $32.8 \%$ during the same period (UniSIS, 2015). The yields of these crops also increased above the national average during 2000-2013: the corn yield grew by $7.1 \%$ annually, soya beans by $6.7 \%$, and wheat by $1 \%$. Wheat is so far the most common crop that covers $25 \%$ of the total crops sown in the CBSR region (UniSIS, 2015).

Some scientists have also noticed a rapid expansion of corn and soybeans (Gavrilin, 2015; Presnyakova, 2013; Naidina, 2013; Sectoral programme, 2014), but their studies focus on the expansion of certain crops rather than any change in the acreage pattern because of the systematic movement. For instance, Gavrilin (2015) discusses the increase in soybeans acreage and focuses on the technology of soybean growing to support the crop yield. Naidina (2013) pays attention to the rising corn acreage to improve yield forecasting.

Sharp increase in corn and soybeans acreage has also raised questions in the business world (Vorotnikov, 2012; Munro, 2013; Doran, 2014). This has clouded the foreseeable future of the Russian agriculture. Recent studies do not provide an answer to this question, as they concentrate on technological aspects of crop cultivation and techniques of rising trend acreage support. 


\section{Introduction}

\subsection{Problem statement}

The rapid expansion of corn and soybeans acreage raises a serious question about any further development of agricultural production in Russia. The important point here is to understand the reasons behind the change in cropping patterns. For this purpose, it is necessary to explore whether it is a temporary occurrence and/or driven by political interventions or whether it reflects a fundamental change in crop economics. The latter, in this case, would imply a lasting change in cropping patterns. A similar transition has occurred in some parts of the US, where corn has become a single crop in a rotational cycle (Taheripour et al., 2015). Cropping pattern changes can also be found in Brazil (Martinelli and Filoso, 2008) and Denmark (Arnberg and Hansen, 2012).

The previously mentioned annual growth rates show that the CBSR has a prominent position in corn and soy production. In 2015 corn and soybeans together occupied $15 \%$ of the total sown area in the region, which is 7.5 times more than that in 2004 (UniSIS, 2015). Presumably, the CBSR has experienced a change in cropping patterns and therefore this region seems to be the most suitable for this study.

Given the size of the region and the role of Russia in the global grain market, any change in cropping patterns would not only have an impact on the development of input and machinery markets in the long run, but also on global agricultural commodity markets. In the 2015-16 marketing year Russia exported 4.4 million metric tonnes of corn and imported 2.2 million metric tonnes of soybeans (USDA database). Fast acreage expenditure of corn and soybeans in the CBSR may potentially result in more corn dampening the global market and subsequently convert the country into a net exporter of soybeans.

Therefore, the aim of this thesis is to determine the current trends, risks, and future directions in the production of cash crops in CBSR of Russia.

To achieve the aim of this dissertation, the following questions need to be answered. First of all, what are the reasons for a change in cropping patterns? The possible causes for any alteration in cropping patterns can be divided into two parts: market and non-market factors. Such division is based on the assumption that, on the one hand, profitability plays the most important role in decisionmaking in well-established markets, on the other hand, non-market factors-for instance, regulatory levers by public authorities - may also play a significant role and rule the agribusiness towards the achievement of political targets such as selfsufficiency. 


\section{Introduction}

The second question is: what is the influence of the change in cropping patterns on the risk profile? Corn and soybeans have different production costs and thus they provide diverse returns. Together with yield variation, it provides a certain risk. Giving access to the planting of corn and soybeans, the question happens to be: what will be the respective shares of crops in different risk perception levels? In other words, how risky would a crop portfolio be with rising shares of corn and soybeans?

The new option for further development of cash crop production in Russia can be traced to genetically modified (GM) seeds. In case of financial constraints, the government is looking for a new source to support and accelerate agricultural production (Gov, 2015). Considering high opportunity costs of countries that do not allow GM technology (Moschini et. al., 2000), the third question is: what possible welfare gains can Russian producers get in case of free access to GM technology? Since getting an access to the technology will influence not only the regional agriculture, but also the entire state, this study should be extended to the country level.

\subsection{Structure and following chapters}

The cumulative dissertation consists of four contributions. Table 1 provides an overview of the included articles, the co-authors, and the journals in which the articles have been published.

Table 1: Overview of the contributions

\begin{tabular}{|c|c|c|c|}
\hline Article & Author(s) & Title & Published in \\
\hline 1. & Chetvertakov S. & $\begin{array}{l}\text { Corn and soy in Russia: } \\
\text { the latest fad or a new } \\
\text { cash cow? }\end{array}$ & 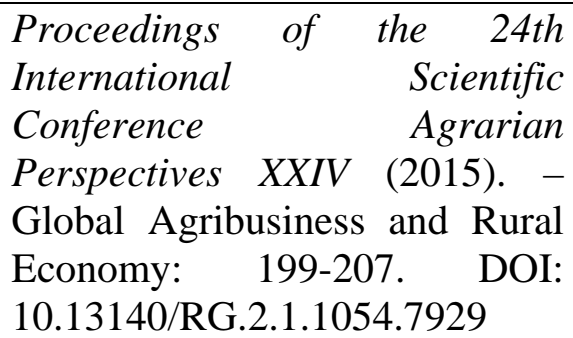 \\
\hline 2. & $\begin{array}{l}\text { Chetvertakov S., } \\
\text { Zimmer Y. }\end{array}$ & $\begin{array}{l}\text { Corn and Soybeans in } \\
\text { the Central Black Soil } \\
\text { Region of Russia: A } \\
\text { fundamental shift in } \\
\text { cropping patterns ahead } \\
\text { of us? }\end{array}$ & $\begin{array}{l}\text { International } \begin{array}{c}\text { Journal of } \\
\text { Agricultural }\end{array} \text { Management, } \\
\text { Volume 5, Number 3, } 1 \text { July } \\
\text { 2016, pp. 44-52(9). DOI: } \\
\text { https://doi.org/10.5836/ijam/201 } \\
\text { 6-05-44 }\end{array}$ \\
\hline 3. & Chetvertakov S. & $\begin{array}{l}\text { Crop choice decision } \\
\text { under uncertainty: a case } \\
\text { study in Russia }\end{array}$ & $\begin{array}{l}\text { Russian Journal of Agricultural } \\
\text { and Socio-Economic Sciences, } \\
\text { Issue } 7 \text { (55), July 2016, pp. 25- } \\
34 \text { ISSN 2226-1184. DOI: } \\
\text { http://dx.doi.org/10.18551/rjoas. } \\
\text { 2016-07.04 }\end{array}$ \\
\hline
\end{tabular}




\section{Introduction}

\begin{tabular}{|l|l|l|l|}
\hline 4. & Chetvertakov S. & $\begin{array}{l}\text { Welfare analysis of } \\
\text { lifting the GM ban in } \\
\text { Russia }\end{array}$ & $\begin{array}{l}\text { AGRIS on-line Papers in } \\
\text { Economics and Informatics, Vol. } \\
\end{array}$ \\
& & $\begin{array}{l}\text { 8, No. 2, pp. 49-56. ISSN 1804- } \\
\text { 1930. } \\
\text { DOI: 10.7160/aol.2016.080204. }\end{array}$ \\
\hline
\end{tabular}

This thesis presents four selected studies on the topic of prospects of cash crop production in the CBSR of Russia.

Article 1 describes the current trend of significant corn and soybeans expansion in CBSR. The paper aims to identify the drivers for a change in cropping patterns and to determine opportunities for further expansion of the mentioned crops.

As outlined in the general background part, possible causes for the alteration in cropping patterns can be split into two parts: market and non-market factors. Hence, a survey was used as the source of information to identify monetary and non-monetary forces influencing the corn and soybeans acreage expansion. This concept results in collection of economic data along with the inquiry of motivation and qualitative issues associated with the shift in cropping patterns at the farm level by understanding better the 'soft factors' behind farmers' decisions regarding corn and soybeans production.

The survey was conducted among farmers in the Voronezh region, which is one of the key areas of the CBSR in terms of production and acreage. Since the data to be collected was rather delicate, face-to-face interviews with farmers were preferred. The interviews were conducted during March 27-April 12 in 2014 with 15 participants. The total acreage of the participating farmers was 391,000 hectares. The participants represented one private farmer, two agroholdings, and 12 medium-sized farms.

The findings of the first article highlight that expansion of the new crops for the region, namely corn and soybeans, is rooted to economic reasons and that neither administrative levers nor subsidies specifically promote these crops. The likelihood of expanding the acreage for soybeans rather than that of corn is higher in this region due to the lower production cost. However, plans for these crops very much depend on the market situation, while decisions about current rotation are revised every year.

The conclusion, besides others, mentions the drawback that the results are ambiguous and cannot distinctly answer the questions. For this reason, the second article has been prepared. 


\section{Introduction}

Article 2 basically raises similar questions as the first one, but analyses more deeply the current situation in Russian cash crop farming. It also attempts to close the 'gaps' in the first article. Therefore, the objectives of the study are:

a) To illustrate the developments in the production of the most important crops from 2000 to 2013

b) To identify the economic drivers of the increases in corn and soybeans production by comparing the profitability from corn and soybeans production with that from wheat, the most important crop in the CBSR

c) To draw conclusions regarding the drivers and perspectives of corn and soybeans production in the CBSR.

To meet the objectives, different research methods, such as the typical farm approach and the focus group discussion method, were applied to prove and improve the findings of the first study. Data from typical farms generated in-depth insights into the economics of corn and soybeans production in Russia. This method is used by the agri-benchmark Cash Crop, and its database contains information about one typical farm in the CBSR.

The focus group discussion took place on 12 November 2014 in Voronezh (Russia). The resulting group consisted of five farmers responsible for their own agricultural businesses or executive managers. Representatives of agroholdings did not attend, and the participants, therefore, represented relatively small-scale farming for Russian conditions (fewer than 10,000 ha per farm).

Two different methods afforded a realistic picture of the economic drivers responsible for the growers' decision by obtaining (a) farm- and crop-specific information and (b) growers' expertise regarding the importance and the 'mode of action' of non-monetary effects associated with individual crops.

The findings reinforce the results of the first article and also showed a higher corn and soy profitability over that of winter wheat as the major factor of their expansion. Farmers can increase corn margins by investing in drying equipment. According to farmers, the further fast growth rate of corn acreage is questionable as it would require additional investment in equipment, but they are willing to increase soybeans acreage.

Results of the first and second articles prove the hypothesis that corn and soybeans are more profitable than wheat. In fact, based on accounting data alone, one would conclude that growers should move to a straight corn-soybeans rotation wherever it is agronomically feasible. However, average profitability is not the only factor in decision-making regarding the choice of crops. Given the uncertainty regarding 


\section{Introduction}

both prices and yields, the risk may impact growers' decisions. Under such conditions, profit maximization, the main goal of any entrepreneur, cannot be exploited uniformly.

In the real world, decision-makers consider both expected return and related risk considering their personal level of risk aversion. Hence, in determining their optimal crop portfolio, farmers should include different crop risk profiles in their decision. 'Optimal' can be defined as the best equilibrium between return and risk by considering the personal risk attitude. Therefore, the crop-choice decision under uncertainty in cash crop farming has been investigated in the third article.

This study aims to calculate the optimal crop portfolio in the CBSR relative to a range of risk aversion for one future marketing year, 2015-2016, as a proxy. This should answer the following question: at what coefficient of relative risk aversion are farmers willing to increase the share of the relatively new crops, namely corn and soybeans? Stochastic simulation is applied as a method of research.

The findings reveal that new crops for the CBSR of Russia, such as corn and soybeans, provide higher returns compared to winter wheat, but bear risk as well. Corn as a monocrop can be optimal only for risk lovers. Slightly risk-averse farmers, which can usually be expected, would diversify production to diminish potential losses. Poor development of insurance services and governmental support force farmers in Russia to use crop portfolio diversification as a risk reducer. In case of a status quo, a future shift to a corn-soybeans rotation or corn as a monocrop, as seen in some parts of the United States (Taheripour et al., 2015), is unlikely.

The possible driver of corn and soybeans expansion in Russia can be the genetic engineering technology, and in the fourth article the author attempts to analyse the welfare effect from lifting the ban on genetically modified herbicide-tolerant soybeans and corn. This study is in line with current discussions on Russian policymakers regarding the genetic modification technology in that country. The article aims to quantify the potential monetary gains from open markets to the genetic engineering technology and accordingly explain the potential additional costs of adapting to the technology. The relevant calculation is based on the supply and demand functions of current market situations and their potential shifts.

The findings reveal that lifting the GM ban in Russia may lead to a considerable increase in the welfare of producers. Considering only two GM crops like corn and soybeans (assuming a 50\% adoption rate and income benefits of \$30 and \$50 per ha for corn and soy, respectively) results in welfare gains equal to the current government subsidies for purchasing elite seeds (MCX, 2015). However, lifting 


\section{Introduction}

the ban for GM seeds will require additional investments to support infrastructure. The estimation of additional costs related to GM crop treatment varies and depends on individual countries and their chosen policies applied to the GM products. Such estimation demands careful calculation as the additional costs in the supply chain can potentially cancel out the increase in the welfare of producers from the costsaving technology. 


\section{Introduction}

\section{References}

Arnberg, S. and L. G. Hansen (2012). "Short-run and long-run dynamics of farm land allocation: panel data evidence from Denmark1." Agricultural Economics 43(2): 179-190.

Doran T. (2014). Corn, soybean export locomotive rolls on. [online] Agrinews. Available at: <http://agrinews-pubs.com/Content/News/Markets/Article/Corn-soybean-export-locomotive-rolls-on-/8/26/10161 > [Accessed 9 May 2014].

Gavrilin, D. (2015). "Effect of sowing dates on seed production of soybean varieties domestic and foreign selection in the conditions of the north-eastern part of the CBSR." Dissertation, Michurinsk, 2015.

Gov (2015), The distribution of subsidies in 2015 to support agriculture, The Russian Government, 2015. [Online]. Available: http://government.ru/docs/16916/ [Accessed 18 March 2015].

Liefert, W. M., and Liefert, O. (2012). Russian Agriculture during Transition: Performance, Global Impact, and Outlook. Applied Economic Perspectives and Policy, 34(1), 37-75. doi: 10.1093/Aepp/Ppr046.

Martinelli, L. A. and S. Filoso (2008). "Expansion of sugarcane ethanol production in Brazil: environmental and social challenges." Ecological Applications 18(4): 885-898.

MCX, 2015. Distribution of subsidies in the directions of the state support, Ministry of Agriculture of the Russian Federation, 2015. [Online]. Available: http://www.mcx.ru/documents/document/v7_show/31252..htm [Accessed 26 April 2015].

Moschini, G., Lapan, H., Sobolevsky, A. Roundup Ready ${ }^{\circledR}$ soybeans and welfare effects in the soybean complex, Agribusiness, 2000, 16(1), 33-55.

Munro E. (2013). Strong corn competition from Russia, Ukraine. [online] Corn and Soybean Digest. Available at: < http://cornandsoybeandigest.com/issues/strong-corn-competition-russia-ukraine > [Accessed 9 May 2014].

Naidina, T. (2013). "Dynamic-statistical model of corn production using satellite data and a method of forecasting the yield". Dissertation, Obninsk, 2013.

Presnyakova, U. (2013). "Varietal specificity of the symbiotic activity of soy in the conditions of forest-steppe CBSR". Dissertation, Voronezh, 2013.

Sectoral program (2014). Sectoral program of the Russian soy union "Development of production and processing of soybeans in Russia for 2015-2020". Moscow, 2014. 


\section{Introduction}

Taheripour, F., Fiegel, J., Tyner, W. E., (2015). Development of Corn Stover Biofuel: Impacts on Corn and Soybean Markets and Crop Rotation. Sustainable Agriculture Research, 5(1), 1.

UniSIS (2015). Unified Interdepartmental Statistical Information System of the Russian Federation [Federal State Statistics Service > Agriculture, hunting and forestry] [online] Available through: <http://www.fedstat.ru > [Accessed 12 May 2014].

USDA database, Production, Supply and Distribution, United States Department of Agriculture Foreign Agricultural Service, 2015. [Online]. Available: http://apps.fas.usda.gov/psdonline/psdQuery.aspx [Accessed 4 August 2015].

Vorotnikov V. (2012). Russia is producing more soybeans and corn. [online] AllAboutFeed. Available at: <http://www.allaboutfeed.net/Nutrition/RawMaterials/2012/3/Russia-is-producing-more-soybeans-and-corn-AAF012875W> [Accessed 9 May 2014]. 


\title{
Corn and soy in Russia: the latest fad or a new cash cow?
}

\author{
Sergey Chetvertakov
}

Institut für Betriebswirtschaft, Thünen-Institut, Bundesallee 50,38116 Braunschweig, Germany sergey.chetvertakov@ti.bund.de

\begin{abstract}
Annotation: Statistical data shows a considerable development of corn and soy production in Russia: from 2000 to 2013 the acreage of these two crops increased by $10.2 \%$ per year. One of the highest growth rates, along with a significant share in the national output, can be found in the Central Black Soil Region, which is one of the main agricultural regions of Russia. The question arises whether this change is a temporary occurrence or whether a fundamental shift in cropping patterns lies ahead. To answer this question, possible reasons for such a shift in the production pattern have been investigated. To collect the data a survey was conducted among farmers in the Voronezh region. Findings revealed mostly economic reasons of the agricultural pattern change. Additional reasons for the crop pattern shift are the existence of necessary infrastructure. However, future plans for discussed crops depend heavily on the market situation and decisions about current rotation are revised by farmers every year. In comparison to corn, the likelihood to extend the soybean acreage is higher in this region due to the lower production cost.
\end{abstract}

Key words: Russia, corn, soy, survey, cropping pattern.

JEL classification: Q130

\section{Introduction}

The breakup of the USSR was the starting point of the transition from a planned to a market economy. The change of the economic and political system substantially affected the agricultural sector: from 1991 onwards production significantly declined, but after the year 2000 a rapid recovery has been observed, primarily in crop production (Liefert and Liefert, 2012). The establishment of markets forced farmers to revise crop preferences, depending on prices and price-ratios generated by markets. New options that have generated some interest are corn and soybeans.

Statistical data shows a considerable increase of corn and soy production in Russia: from 2000 to 2013 the acreage of these two crops increased by $10.2 \%$ per year. One of the highest growth rates, along with a significant share in the national output, can be found in the Central Black Soil Region (CBSR): corn acreage increased from 2000 to 2013 by $17.3 \%$ annually, soy acreage gained $32.8 \%$ annually in the same period ${ }^{18}$. The question arises whether this change is a temporary occurrence or whether a fundamental shift in cropping patterns is to be expected.

There have been several debates in the media about further expansion of these crops (Vorotnikov, 2012; Munro, 2013; Doran, 2014). However, no scientific research or detailed analysis of these changes has been carried out. For this reason this paper aims to:

- $\quad$ identify drivers for a crop pattern change;

- determine opportunities of further corn and soy expansion.

18 own calculations based on UniSIS (2014) 
The possible causes for the alteration in crop patterns are divided into two parts: market and non-market factors. Such division is based on the assumption that, on the one hand, in well-established markets, profitability plays the most important role in decision making. On the other hand, non-market factors (for instance, regulatory levers by public authorities) may also play a significant role and rule the agribusiness towards achievement of political targets, such as self-sufficiency.

Thorough investigation of the Food Security Doctrine of Russia (FSDRF, 2010), which is the main political document regarding the self-sufficiency level and core of agricultural development for the near future, revealed a lack of any special targets for soy and corn set by politicians. Therefore, the economic reasons will be investigated first.

Economic causes on a farm level can, in principle, be identified by official profit and loss figures, which farms report to local authorities. However, they cannot be used exclusively due to the following limitations:

1) The information is too general - collected data ${ }^{19}$ is summarized at a regional level and does not represent the farms information separately. A general finding of several authors points out that the variability of farms is enormous and remains hidden when averages are used (Nivyevskiy, von Cramon-Taubadel and Grueninger, 2008; Rylko et al., 2008; Slaston and Larsén, 2010; Byerlee, Lissitsa and Savanti, 2012);

2) Such figures entail an inherent risk of being biased because they have been created for reports to tax authorities. Under such conditions there is a strong incentive for producers to lower profits. Therefore, it is most likely they do not reflect the true economic conditions.

Understanding economic reasons for a change in cropping patterns requires detailed information on cost and returns for individual crops. Furthermore, one needs to also take into account possible interactions between crops because of agronomical benefits and cost caused by individual crops (Albrecht, 2015). Thus to identify economic reasons and blocks influencing the corn and soy acreage expansion, a survey will be used as the source of information.

This paper is organized as follows: the second section describes the methods which will be used in the paper to analyze the issues. The third section provides economic analysis of corn, soybeans and winter wheat and a review of existing farm infrastructure. Conclusions will come at the end of the paper.

\section{Materials and Methods}

The survey may provide empirical information - discloses information on all relevant inputs and outputs in terms of quantities and prices. Strength of this approach is a consistency of figures: data is relevant to particular farms, as opposed to regional averages. Moreover, this concept allows the inquiry of motivation and qualitative issues associated with the shift in cropping patterns on a farm level and better understands "soft factors" of farmers' decisions regarding corn and soybean production. Nevertheless, the disadvantages of the survey method are: the inability to verify the data provided, the study is time consuming

\footnotetext{
${ }^{19}$ Total profit, level of profitability, assets and debts of agricultural sector
} 
and has relatively high financial costs, as well as the possible lack of representativeness of the sample group when transferring the findings to a larger group.

In respect to the aforementioned annual growth rates, the CBSR has the most prominent position in corn and soy production. Therefore, this region seems the most suitable for the study. Given financial restrictions to collect the data a survey was conducted among farmers in the Voronezh region, which is one of the key regions in terms of production and acreage of CBSR: the total crop acreage in 2013 reached 2.6 million hectares (27\% of the CBSR acreage).

Because the data which is to be collected is rather delicate (cost, revenue, existence of sufficient infrastructure and etc.) face to face interviews with farmers are preferred. Details of farmers from 89 farms were found using a list of names and phone numbers of corn and soybean growers provided by the Voronezh Region Agricultural Policy Department ${ }^{20}$. The interviews were conducted from March 27 to April 12, 2014. It was not possible to contact all farmers on the list and even fewer expressed the readiness to participate in an interview. Only those farmers growing corn and/or soybeans for three years or more were interviewed to exclude farmers who just test these crops and have not adjusted the production system yet. Ultimately, the interview was conducted with 15 correspondents and each lasted for about 1 hour. The total acreage of participating farmers is 391 thousand hectares, which represents $15 \%$ of the total Voronezh region acreage.

In the first phase preliminary calls were made to farmers in order to get acquainted and to explain the research, as well as asking about the opportunity to meet for interview. Once agreed, the next step was face to face structured interviews with the responsible person (manager or agronomist). The main targets of asking questions were: to get economic data for crop net-return comparison; investigate farmers' experience and their impression of growing corn and soybeans; plans for growing in the near future. Questions represent a combination of open and closed questions ${ }^{21}$.

Most popular crops among farmers in the CBSR are small grains, among them - winter wheat. This is the only crop grown in all studied farms and the most common so far (in 2013 it accounted for $24 \%$ of total crop acreage of the Voronezh region). For this reason, corn and soybeans will be compared to winter wheat.

\section{Economics and farming conditions of major CBSR arable crops}

\subsection{Farm economics}

As stated above, 15 interviews were conducted to obtain more insight on the ground level. It should be noted that not all respondents were able to answer all the questions, especially regarding economic indicators (cost, price etc.). Thus, only the performance of those farms that had sufficient data to calculate the results has been presented.

The overall composition of the respondents can be described as follows: 1 private farm, 12 independent enterprises or members of agricultural holdings and 2 headquarters of agricultural holdings, which manages a number of farms. In terms of arable land, the private

\footnotetext{
${ }^{20}$ State executive authority of Voronezh Region

${ }^{21}$ questionnaire is available upon request from the author
} 
farmer has around 650 ha, the 2 agroholdings have 60,000 ha and 250,000 ha respectively and land belonging to other farms is somewhere between 3,000 ha and 12,000 ha. Farm data is coded using letters to secure its confidentiality. The share of corn in rotations among farms varies from $5 \%$ to $50 \%$ and soybeans - from $2 \%$ to $23 \%$.

In order to compare the economic performance of selected crops information about cost and revenue is required. The questions asked aimed to find out the normal, expected farming conditions and eliminate possible biases of specific conditions in one year. Therefore, farmers were asked to indicate answers related not to a particular year, but to the average for the 2011-2013 period. Respondents were asked about the average for the selected time frame farm gate prices per ton, yield per ha under standard moisture and total cost per hectare to calculate the economic indicators. It is very important to mention that the selected time frame is characterized by relatively low fluctuation in the mentioned criteria.

Market revenue per ha in this paper is calculated as crop yield per ha multiplied by the farm gate price per ton. The difference between the market revenue and the total cost is the profit. All economic data is in the local currency but for comparison was recalculated to USD using the annual average ratio of the Russian Ruble to USD. As economic performance is a rather sensitive question, in this part of the interview farmers were able to give a 'non-response' which, for corn growers accounted for $40 \%$ of responses and $33 \%$ for soybean growers. The main reason used by farmers for 'non-response' was the absence of such information.

Table 1. Revenue and cost for the focus crops in surveys farms, USD per hectare

\begin{tabular}{|c|c|c|c|c|}
\hline Farms & Crops & Total cost & Market revenue & Profit \\
\hline \multirow{3}{*}{$A$} & Wheat & 474.3 & 1092.1 & 617.8 \\
\hline & Corn & 550.8 & 1373.6 & 822.8 \\
\hline & Soybeans & 541.6 & 1133.7 & 592.1 \\
\hline \multirow{2}{*}{ B } & Wheat & 459.0 & 856.8 & 397.8 \\
\hline & Corn & 612.0 & 841.5 & 229.5 \\
\hline \multirow{3}{*}{ C } & Wheat & 489.6 & 856.8 & 367.2 \\
\hline & Corn & 612.0 & 1049.6 & 437.6 \\
\hline & Soybeans & 336.6 & 884.3 & 547.7 \\
\hline \multirow{3}{*}{ D } & Wheat & 452.9 & 918.0 & 465.1 \\
\hline & Corn & 673.2 & 1072.2 & 399.0 \\
\hline & Soybeans & 428.4 & 881.3 & 452.9 \\
\hline \multirow{3}{*}{ E } & Wheat & 367.2 & 979.2 & 612.0 \\
\hline & Corn & 612.0 & 1224.0 & 612.0 \\
\hline & Soybeans & 397.8 & 1248.5 & 850.7 \\
\hline \multirow{3}{*}{$\mathrm{F}$} & Wheat & 218.8 & 765.0 & 546.2 \\
\hline & Corn & 372.4 & 1453.5 & 1081.1 \\
\hline & Soybeans & 292.4 & 814.0 & 521.6 \\
\hline \multirow{2}{*}{ G } & Wheat & 550.0 & 610.5 & 60.5 \\
\hline & Corn & 900.0 & 1468.8 & 568.8 \\
\hline \multirow{3}{*}{$\mathrm{H}$} & Wheat & 428.4 & 820.1 & 391.7 \\
\hline & Corn & 520.2 & 936.4 & 416.2 \\
\hline & Soybeans & 306.0 & 918.0 & 612.0 \\
\hline \multirow{2}{*}{ I } & Wheat & 489.6 & 840.0 & 350.4 \\
\hline & Corn & 550.8 & 1468.8 & 918.0 \\
\hline \multirow{3}{*}{ Mean } & Wheat & 436.6 & 859.8 & 423.2 \\
\hline & Corn & 600.4 & 1209.8 & 609.4 \\
\hline & Soybeans & 383.8 & 980.0 & 596.2 \\
\hline \multirow{3}{*}{ Standard Deviation } & Wheat & 95.5 & 134.5 & 170.3 \\
\hline & Corn & 140.9 & 243.8 & 278.5 \\
\hline & Soybeans & 93.5 & 170.9 & 136.7 \\
\hline
\end{tabular}


The main indicator of crop preference for farmers in free market conditions is profit per hectare. From Table 1 one can conclude that investigated farms do not have a common denominator. But with regard to the general trend, the calculation of the mean profit per hectare for this sample shows that corn brings the highest average return with 609 USD/ha, followed by soybeans with 596 USD/ha, in third place was winter wheat with 423 USD/ha. Corn was more profitable than winter wheat for 6 out of 9 respondents, one farm (E) had equal profit for two these crops and for 2 farms ( $B$ and $D$ ), wheat gained more profit than corn.

For soybean producers this comparison shows that for half of them (three out of six) winter wheat was more marginal, but the difference is rather small: from $3 \%$ to $5 \%$ of profit. However for the other half, profit from soybeans exceeded that of winter wheat by about $50 \%$. Such a large difference in values can be linked to the relative newness of growing corn and soybeans which requires each farm to adjust its production system.

Box-and-whisker plot of profit (Fig. 1) allows to better understand how profit values are spaced out in different sets of crop data. The left whisker of the boxes represents the $25^{\text {th }}$ percentile, while the right represents the $75^{\text {th }}$. The whiskers extend to the highest and lowest observation unless they are more than 1.5 box-lengths long. Observations outside this range are plotted as circles. The vertical line inside of the boxes is the median.

Fig. 1. Box-and-whisker plot of profit for the focus crops

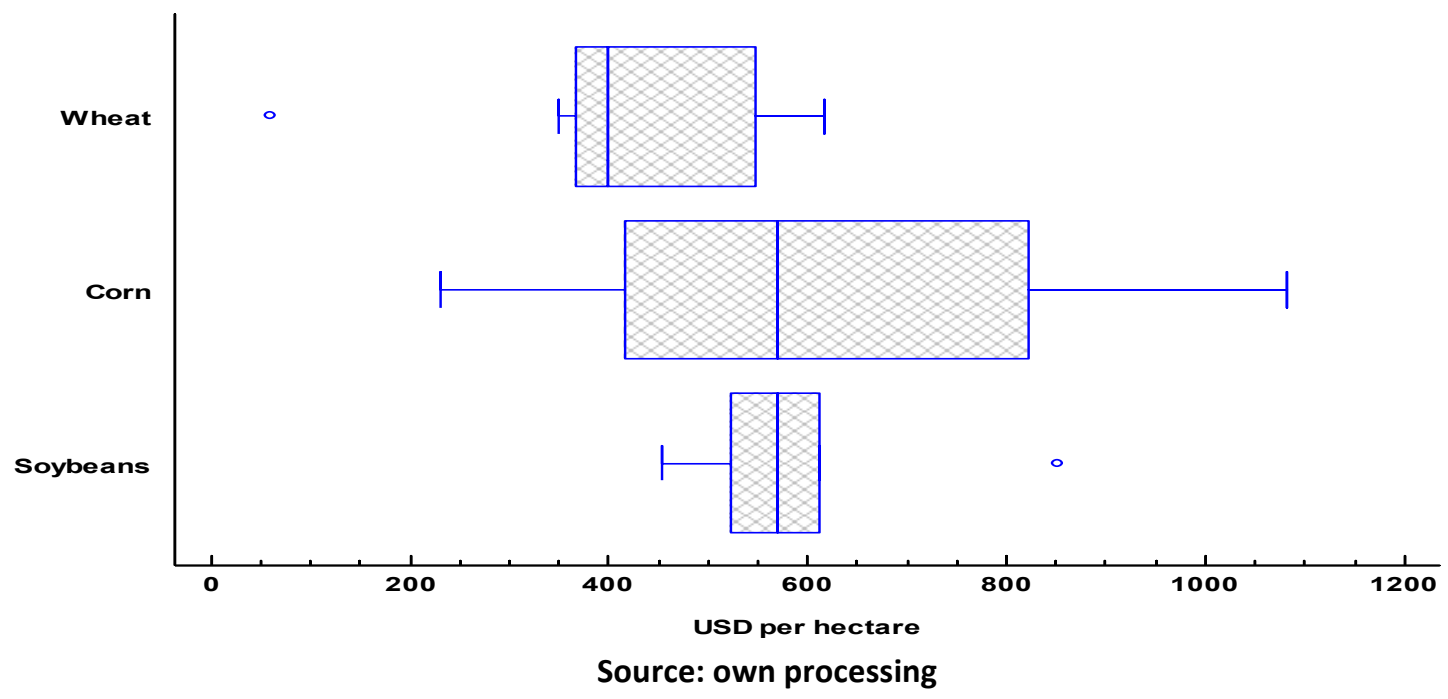

The profit data sets have different coefficients of variation: $40.2 \%, 45.7 \%$, and $22.9 \%$, respectively for wheat, corn, and soybeans. They indicate that profit from soybeans is less spread out. Of particular interest is that the coefficient of standardized skewness for profit distribution are negative for wheat and positive for corn and soybeans. This indicates that the left side tail of wheat distribution is longer or fatter than the right side and opposite is true for corn and soybeans.

The cost ratio comparison for corn, soybeans and wheat can be beneficial in understanding the farmer's decisions. Firstly, more expenses can be associated with a larger loss in the event of failure. This risk may be mitigated by insurance, which is a commonly used instrument all over the world (Vilhelm, 2011). But the market for such service is underdeveloped in Russia in 2014 only $17.7 \%$ of the total acreage was insured (NAAI, 2015). Secondly, these expenses demand larger sums of investment which increases the financial burden for farmers and requires additional resources. 
Fig. 2. Cost per ha ratio for surveys farms

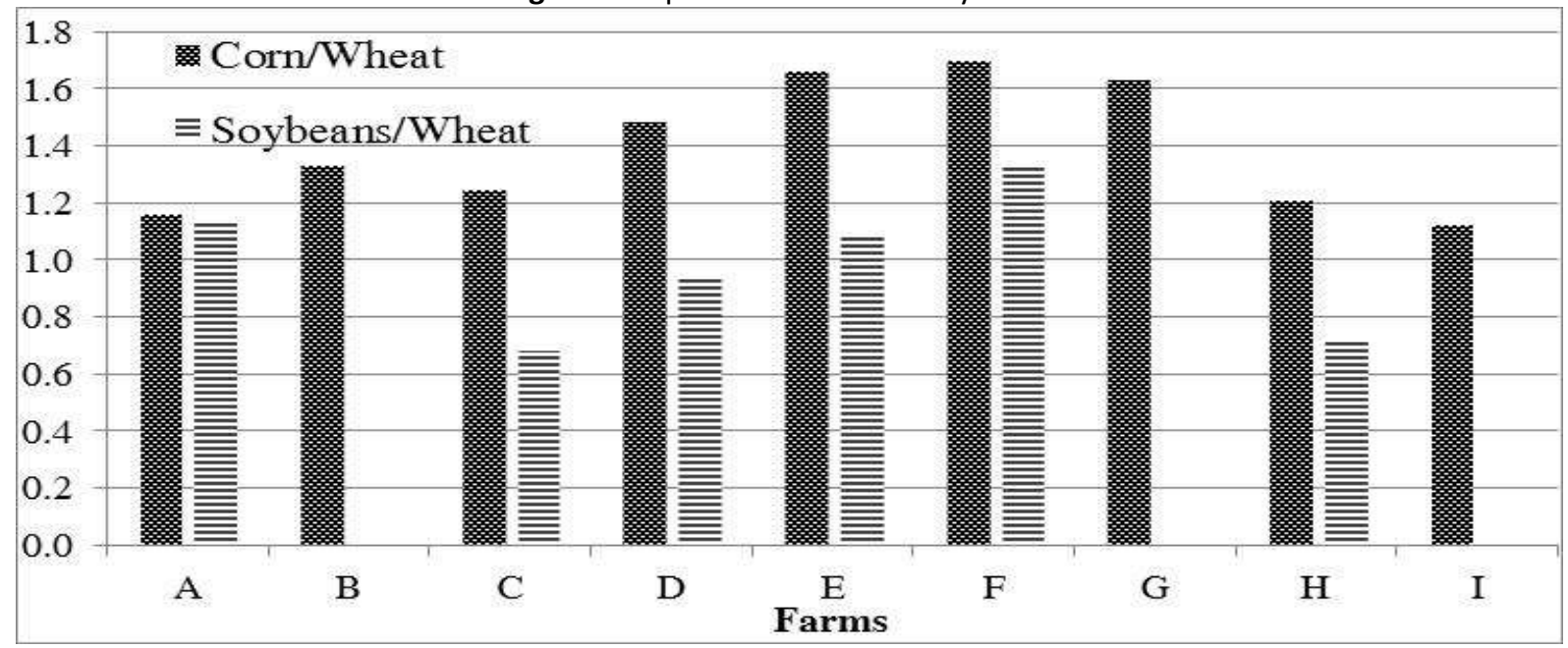

Source: own processing

Figure 2 shows that corn requires more financial input than winter wheat. The difference varies from $10 \%$ to $70 \%$ of cost per ha. The difference of total costs between corn and winter wheat can be mainly associated with the higher cost per ha of fertilizers and wheat seeds (this is notable in Russia, where farmers use high-yielding corn hybrids which are purchased each year and the use saved wheat seeds). The total cost of soybeans is not as consistent as that of corn. For half of respondents the cost of soybeans surpasses that of winter wheat, while for the other half the ratio is under 1.

\subsection{Framework conditions for corn and soybean expansion}

Establishment of new crops in the production system requires farmers to assess not only the outcomes, such as profit per ha, but also necessary infrastructure and additional investments for its construction. Conducted interviews included questions about infrastructure. Existing facilities of infrastructure can serve as motivation for growing and the lack of it may become a deterrent for the reorganization of the production pattern.

Questions for the respondents included narrowly focused questions to clarify the power of influence of hypothetical factors, as well as open-ended questions to identify potential issues during the establishment of corn and soybean production, which could have slipped by the interviewer. Before the interviews, the next factors were determined as potential restrictions:

1) Storage -corn usually has a higher yield in comparison to wheat and requires a higher capacity of warehouses;

2) Drying capacity - the harvesting period of corn and soybeans occurs in autumn (in comparison with summer harvesting of small grains), when the temperatures are less likely to allow grains to loose moisture naturally. For storage and trading purposes the moisture content has to meet a conditional level that often demands additional drying;

3) Transport - again, because of the higher yield, corn requires additional transporting capacity.

The respondents' answers indicate the presence of the necessary infrastructure. Lack of storage facilities was only noted by 1 farmer out of 15 . The remaining farmers have storage capacity for more than half of the output. These warehouses were often built in Soviet times 
with the bulk storage method. Agricultural holdings, as vertically integrated companies, have their own elevators in assets.

For drying, many interviewees invested in special equipment. Out of 15 corn growers 12 have drying equipment, 2 more farmers expressed their willingness to purchase such equipment in the near future. According to the farmers, availability of one's own drying capacity allows for the accumulation of larger margins for the farm and increases flexibility with regard to the changing weather and market conditions.

The issue with transportation of larger quantities of grains according to farmers is not an uphill task. Vehicles for grain shipping are often produced domestically and relatively cheaply. All farmers expressed that there is a high supply of contractors and in the case of a capacity shortage, especially in peak periods, hired contractors with low costs can be hired.

Initial assumption that corn and soy growing can be promoted by politicians was also tested during the interview. Answers show the absence of any administrative levers. Existing subsidies have a very low share in costs and are not allocated to a particular crop, but on a hectare basis. Therefore, author assumes the absence of external factors which can potentially distort farmer's decisions regarding crop acreage allocation.

Additional issues which author has not taken into account are that several farmers expressed the need to purchase harvesting equipment. Further expansion of corn as a production threshold is a deterrent for farmers with regard to the current production system.

For future prospects of the studied crops, respondents were asked about the intention to increase corn and soybean acreage. Among respondents no-one had the specific intent to increase land for corn production. The reasons were: shortage of sufficient equipment and a focus on improvement and adjustment of current production technology rather than acreage expansion. Two farmers were going to decrease corn acreage due to the expansion of sugar beet production. However, most of the respondents had difficulty in citing a reassessment of planted areas every year on the basis of market prices.

The situation with soybeans is more obvious. Among respondents, 7 out of 15 farmers grow soybeans and 3 of them expressed intention to increase the crop acreage. The remaining 4 in the short term will keep the amount of crops at the same level. In addition to this, out of the 8 respondents who had never grown soybeans, 4 intend to plant it in the coming season.

With regard to possible opportunities, further increase of soybean acreage can be expected as it requires less cost in comparison to corn and at the same time provides high returns. Further corn expansion can be slowed down by significant cost demands not only for planting, but also for establishing efficient infrastructure with modern storage methods and drying. Agroholdings, as agricultural units with sufficient financial resources, will drive corn expansion, but further expansion is unlikely for small-scale farms.

Low interest rate could also stimulate large investments for new highly profitable crops, but current situation in Russia is not in favor of taking credit (CBR, 2015). However, another factor is beginning to play a role - establishment of export fee for wheat (Gov, 2015). Such fee will make wheat planting less attractive, and meanwhile increase opportunities of further soybean and corn acreage expansion. 


\section{Conclusion}

The CBSR is a new hotspot for corn and soybean production. Findings revealed that corn and soy acreage expansion are rooted to economic reasons. Neither administrative levers nor subsidies promote the growing of corn and soybeans.

Findings have revealed that economic reasons were responsible for the change in the agricultural pattern. Farmers reap more profit per hectare from corn and soybeans in comparison to winter wheat. The cost for corn is greater than for winter wheat (the mean cost of corn production is 600 USD per ha, whereas for winter wheat it is 437 USD per ha) that puts additional pressure on the financial situation of farmers and in the event of crop failure it would lead to higher losses. It requires farmers to manage risks more carefully. The introduction in a production pattern of soy requires less cost (mean cost of soy production is 384 USD per ha) and can generate higher returns than wheat, which is so far the most important cash crop in this region. Such a superior condition of soy encourages farmers to invest in this crop. From an agronomic point of view soy has better manageability in existing rotations in comparison to corn. The likelihood of expanding the soybean acreage rather than that of corn is higher in this region due to the lower production cost.

One reason for the crop pattern shift is the existence of infrastructure. However, as is evident from farmers' attitudes, future plans for discussed crops very much depends on the market situation and decisions about current rotation are revised every year. Current factors influencing Russian crop production are ambiguous and future perspectives are difficult to determine.

\section{Acknowledgements}

This paper was prepared with the financial support of the agri benchmark Cash Crop Network (http://www.agribenchmark.org). The author grateful to Dr. Yelto Zimmer for very helpful comments and advice on an early draft of this paper and to Amy Cooper for language corrections of the paper.

\section{References}

Albrecht, R. (2015) 'Ein Ansatz zur Abschätzung der interregionalen Wettbewerbsfähigkeit der Zuckerrübenproduktion - am Beispiel ausgewählter europäischer Regionen'. Braunschweig: Thünen-Institut, Bundesforschungsinstitut für Ländliche Räume, Wald und Fischerei, Thünen Rep 24.

Byerlee, D., Lissitsa, A. and Savanti, P. (2012) 'Corporate models of broadacre crop farming: international experience from Argentina and Ukraine', Farm Policy Journal, vol. 9, no. 2, pp. 13-25, ISSN 1449-8812

CBR, Home page of The Central Bank of the Russian Federation, 2015. [Online]. Available: http://www.cbr.ru/ [Accessed: 24 June 2015].

Doran, T. (2014) Corn, soybean export locomotive rolls on. [Online]. Available: http://agrinewspubs.com/Content/News/Markets/Article/Corn--soybean-export-locomotive-rolls-on/8/26/10161 [Accessed: 10 May 2015].

FSDRF, Food Security Doctrine of the Russian Federation, 2010. [Online]. Available: http://www.mcx.ru/documents/document/show/14857.19.htm [Accessed: 4 March 2015]. 
Gov, Постановление Правительства России 'Об установлении ставки вывозной таможенной пошлины на пшеницу, 2015. [Online]. Available: http://government.ru/ docs/18291/ http://government.ru/docs/18291/ [Accessed: 24 June 2015].

Liefert, W. M. and O. Liefert (2012) 'Russian Agriculture during Transition: Performance, Global Impact, and Outlook', Applied Economic Perspectives and Policy, vol. 34, no. 1, pp. 3775, ISSN 2040-5804.

Munro, E. (2013) Strong corn competition from Russia, Ukraine. [Online]. Available: http://cornandsoybeandigest.com/issues/strong-corn-competition-russia-ukraine [Accessed: 9 May 2014].

NAAI, International round table of NAAl: agricultural insurance in Russia prepares for a new stage, National Association of Agriculture Insurers, 2015. [Online]. Available: http://www.naai.ru/eng/press-tsentr/nsa_news/international_round_table_of_naai_ agricultural_insurance_in_russia_prepares_for_a_new_stage/ [Accessed: 23 June 2015].

Nivyevskiy, O., von Cramon-Taubadel, S. and Grueninger, M. (2008) 'Ukraine: Agricultural Competitiveness', World Bank Policy Note. Report No 44843-UA

Rylko, D., Khramova, I., Uzun, V. and Jolly, R. (2008) 'Agroholdings: Russia's New Agricultural Operators', In: Lerman Z (Editor): Russia's agriculture in transition: factor markets and constraints on growth, pp. 95-131, Lexington Books, Lanham

Slaston, R. and Larsen, K. (2010) 'Assessment of Efficiency and Impact of specific factors on Wheat Cultivation in Ukrainian Agricultural Enterprises' The 114th EAAE Seminar Structural Change in Agriculture, Berlin, pp. 15-16.

UniSIS, Unified Interdepartmental Statistical Information System of the Russian Federation, 2014. [Online]. Available: http://www.fedstat.ru/ [Accessed: 12 May 2014]

Vorotnikov, V. (2012) Russia is producing more soybeans and porn. [Online]. Available: http://www.allaboutfeed.net/Nutrition/Raw-Materials/2012/3/Russia-is-producing-moresoybeans-and-corn-AAF012875W/ [Accessed: 10 May 2014]

Vilhelm, V. (2011) 'The Role of Public Support of Risk Management in Agriculture', Proceedings of the Conference Agrarian perspectives XX, Prague, pp. 179-186. ISBN 978-80-213-2196-0 


\title{
REFEREED ARTICLE
}

\section{Corn and Soybeans in the Central Black Soil Region of Russia: A fundamental shift in cropping patterns ahead of us?}

\author{
SERGEY CHETVERTAKOV ${ }^{1,2}$ and YELTO ZIMMER ${ }^{1}$
}

\begin{abstract}
Recent statistics show an increase in corn and soy production in the Voronezh region, one of Russia's most important agricultural regions. This paper analyses the background of and the reasons for this development. To achieve this goal, the authors used data from agri benchmark typical farms and focus group discussions with farmers in Russia. The resulting analysis discloses the economic drivers of these changes in cropping patterns which clearly indicate a lasting shift in the Black Soil Region towards corn and soybean production.
\end{abstract}

KEYWORDS: Russia; corn; focus group discussion; cropping pattern; on-farm competitiveness of crops

\section{Introduction}

\section{Background}

The dissolution of the former Soviet Union set in motion the shift from the planned economy to a market economy. This structural modification of the political and, at the same time, the economic system has affected the agricultural sector. Starting in 1991, a significant decline in agriculture was observed; beginning in 2000, the entire sector, but especially crop production, headed toward a rapid recovery (Liefert \& Liefert, 2012). The establishment of markets forced farmers to alter crop preferences based on prices and price ratios generated by the markets. New and interesting options were corn and soybeans.

Statistical analysis of Russian crop production reflected a significant rise in the cultivation of corn and soybeans albeit beginning from a very low level. One of the strongest growth rates, and accounting for a significant share in the national output, can be found in the Central Black Soil Region (CBSR) (UniSIS, 2014). The question arises whether this change is a temporary occurrence, possibly driven by political interventions, or whether it reflects a fundamental change in crop economics which would imply a lasting change in cropping patterns.

When considering global crop production, a comparative example of fundamental change occurred during the past 20 years in southern Canada and the northern United States where corn and soybean production has expanded dramatically (Wright \& Wimberly, 2013). Given the fact that there are climatic and agronomical similarities between the Central Black Soil Region and these North American regions, the question is whether the CBSR might evolve in a similar way in terms of cropping patterns. Given the size of the region and Russia's role in global grain markets in the long run this not only would have an impact on the development of the respective input and machinery markets, but also on global agricultural commodity markets.

\section{Aim of the paper}

So far, very few articles about the expansion of these crops have been published in the Russian media (Vorotnikov, 2012; Munro, 2013; Doran, 2014). In science, this issue has not yet been addressed. For these reasons, this paper aims to identify drivers of a change in cropping patterns in the CBSR.

To achieve this objective, the first task is to illustrate the production development of the most important crops from 2000 to 2013. Secondly, this paper identifies economic drivers for the increase of corn and soybean production by comparing the profitability of corn and soybean production to the most important crop in the CBSR which is wheat. Finally, the authors draw conclusions regarding the drivers and perspectives for corn and soybean production in the CBSR.

\section{Organization of the paper}

This paper is organized as follows: The second section reviews the development of the most important crops grown in the CBSR. The third section discusses the methods used in the paper. The benchmark, with an economic analysis of corn, soybeans and winter wheat is introduced in section four. The last part summarizes main findings and provides some conclusions.

\footnotetext{
Original submitted June 2015; revision received May 2016; accepted May 2016.

${ }^{1}$ Thünen Institute, Braunschweig, Germany.

${ }^{2}$ Corresponding author. Chetvertakov Sergey, Thünen-Institut für Betriebswirtschaft, Bundesallee 50, 38116 Braunschweig, Germany. E-mail: sergey.chetvertakov@ti.bund.de.
} 
Table 1: Corn and soybean production in Russia - key parameters (2000 vs. 2013)

\begin{tabular}{|c|c|c|c|c|c|}
\hline Crop & Federal districts & $\begin{array}{c}\text { Increase } \\
\text { in acreage } \\
\text { (\% per year) }\end{array}$ & $\begin{array}{c}\text { Increase } \\
\text { in yield } \\
\text { (\% per year) }\end{array}$ & $\begin{array}{c}\text { Share } \\
\text { in national } \\
\text { output (2000) }\end{array}$ & $\begin{array}{c}\text { Share in } \\
\text { national } \\
\text { output (2013) }\end{array}$ \\
\hline Corn & $\begin{array}{l}\text { The Russian Federation } \\
\text { Central Federal District } \\
\text { Southern Federal District } \\
\text { Volga Federal District } \\
\text { Far Eastern Federal District } \\
\text { Other } \\
\text { The Russian Federation } \\
\text { Central Federal District } \\
\text { Southern Federal District } \\
\text { Volga Federal District } \\
\text { Siberian Federal District } \\
\text { Far Eastern Federal District } \\
\text { Other }\end{array}$ & $\begin{array}{r}10.2 \\
17.3 \\
5.8 \\
15.4 \\
14.9 \\
- \\
10.2 \\
32.8 \\
7.9 \\
29.1 \\
17.7 \\
8.1 \\
-\end{array}$ & $\begin{array}{l}5.7 \\
6.8 \\
5.7 \\
- \\
7.9 \\
- \\
3.4 \\
6.6 \\
4.2 \\
5.6 \\
0.9 \\
2.9 \\
-\end{array}$ & $\begin{array}{r}100 \% \\
19.2 \% \\
71.1 \% \\
8.9 \% \\
0.7 \% \\
0.0 \% \\
100 \% \\
1.9 \% \\
20.1 \% \\
0.5 \% \\
1.4 \% \\
76.0 \% \\
0.1 \%\end{array}$ & $\begin{array}{r}100 \% \\
32.7 \% \\
37.8 \% \\
5.3 \% \\
1.3 \% \\
22.9 \% \\
100 \% \\
30.9 \% \\
20.9 \% \\
4.4 \% \\
1.2 \% \\
39.5 \% \\
3.1 \%\end{array}$ \\
\hline
\end{tabular}

Source: own calculations based on official statistics (UniSIS, 2014).

\section{Evolution Of Cropping Patterns In Russia And The CBSR}

\section{Selection of region for the study}

Currently, the leading producer of corn in Russia is the Southern Federal District (see Table 1), a traditional area for corn cultivation, where the growth of acreage and yields was relatively small in the period studied. On the other hand, the Central Federal District has significantly increased its share of the national production; a change due to high growth rates of corn acreage and yield. At the same time, the Southern Federal District suffered a decline in market share.

Growth rates of soybean acreage reflect a geographical relocation of this crop to the west. In 2000, $76 \%$ of soybeans were produced in the Far Eastern Federal District; its share dropped (despite an absolute increase in production) to $59 \%$ by 2012 and to $39.5 \%$ in 2013 (the latter decrease was in part driven by a massive crop loss as a result of severe flooding). Further increases in soybean plantings in the Far Eastern Federal District seem unlikely, as the share of this crop in the sown acreage already is $58.6 \%$. In the Amur region (part of the Far Eastern Federal District), which produces the majority of the district's soybeans, this proportion is even higher, at $70 \%$. Due to the high growth rates both in soybean acreage and yield in the Central Federal District, its share of the national output reached $30.9 \%$ in 2013, while it was only $1.9 \%$ in 2000 .

The data cited show that the Central Federal District became a "hot spot" of corn and soybean in Russia. Since so-called "Central Black Soil Region" is a region defined by agro-ecological parameters and $94 \%$ of the Central Federal Districts corn and $97 \%$ of the soybean production takes place in the Black Soil Region this regional unit will be referred to in the remainder of the paper.

\section{Key characteristics of crop production in the CBSR}

Natural and geographic conditions

Central Black Soil Region is one of 11 economic areas of the Russian Federation, which includes the regions of the southern part of Central Russia, such as Belgorod, Voronezh, Kursk, Lipetsk, Tambov and Orel (ASVR, 2014).
The total sown area of the region in 2013 was 9.6 million ha, which is $12.3 \%$ of the all cultivated land in Russia. The annual precipitation in the region varies between $518 \mathrm{~mm}$ and $648 \mathrm{~mm}$ and average annual temperatures range from 6.1 to 7.7 degrees Celsius (Climate, 2014).

\section{Acreage and yields of major crops}

Agricultural background information of a region requires knowledge about its most important crops. For this task, statistics regarding all agricultural land in the CBSR were analysed. In 2013, the largest share had cereals, with $59 \%$ of the sown land in the CBSR. The largest share of cereals was winter wheat, with $27 \%$ of the total cultivated area. Among non-grains, the largest acreage was planted to sunflowers, with $14 \%$. Sunflower was not planted by all farms studied. The authors compare winter wheat, so far the most popular crop, corn, and soybeans.

Figure 1 shows that the acreage cultivated with the observed crops is increasing. Because there has been a huge portion of the farm land being idle ${ }^{3}$ this growth stems from (a) an increase in total cropped land and (b) shifts in cropping pattern in favour of winter wheat, corn and soybeans.

The $3.7 \%$ average annual growth in land planted to winter wheat is the smallest among the analysed crops. With average growth rates of $17.2 \%$ and $32.8 \%$, corn and soybeans show the highest annual increase in seeding. Whereas, in 2000, winter wheat was widely cultivated, corn and soybeans covered only $1.4 \%$ of the CBSR's crop land; their growth spurt led to approximately $10 \%$ of the cultivated land in 2013.

One possible explanation for this change in cropping patterns is the evolution of yields (Figure 2). Yields of winter wheat in the first phase of the analysed period were similar to or even better than those of corn. From 2003 onwards, the situation changed: corn yields improved significantly while wheat yields were almost flat. In 2012 corn yielded 2.5 tons per hectare more than winter wheat. Although soybeans in 13 years doubled its productivity, it has not reached the level of 2 tons per hectare.

Compared to the other crops the annual increase in wheat yields is almost flat at $1.5 \%$ while soybeans and

${ }^{3}$ In the post-Soviet economic transition period, much land was abandoned. When analyzing the CBSR from 1990 to 2006 when arable land use was the lowest about 3.5 million hectares or $31 \%$ were not cultivated. Starting in 2007 , the trends reversed and in 2013 about 9.6 million hectares were cropped (or $83 \%$ of the level of 1990). 


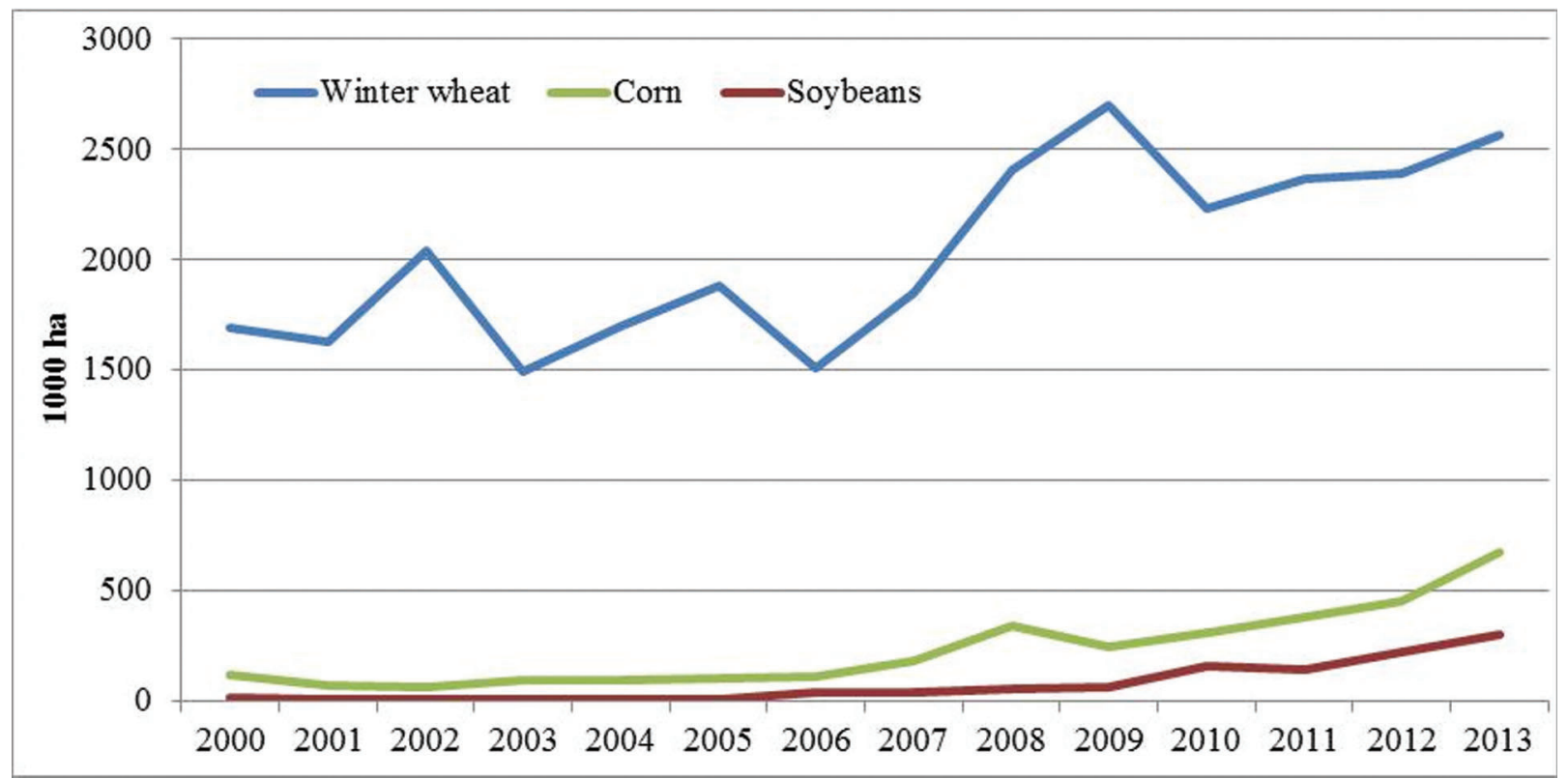

Figure 1: Evolution of selected crops' acreage in the CBSR Source: UniSIS (2014) and own calculations

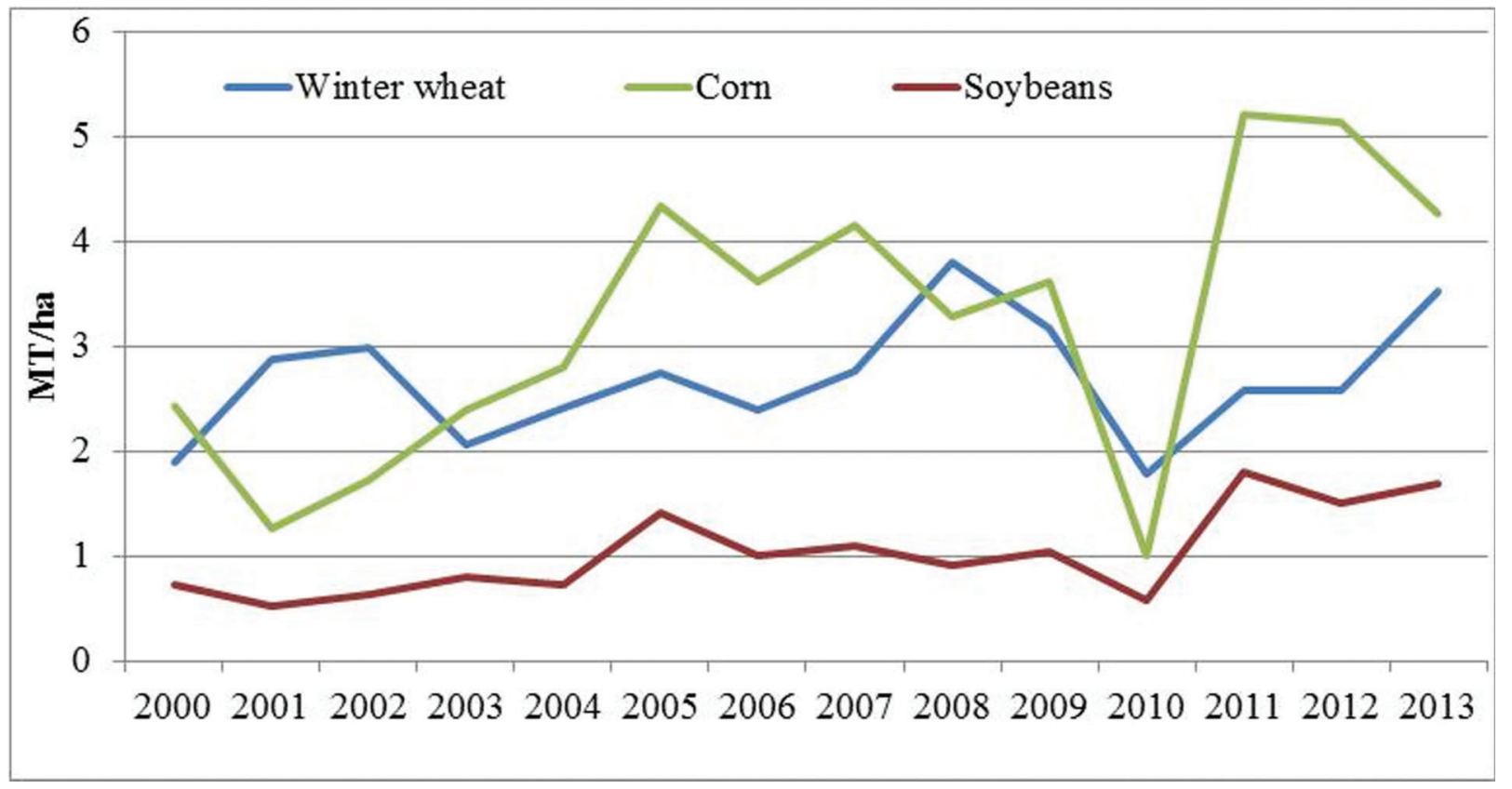

Figure 2: Yield (calculated as the output from the sown area) - evolution of the selected crops in the CBSR Source: UniSIS (2014), own calculations

corn yields went up by $6.7 \%$ and $6 \%$ respectively. These annual rates were significantly influenced by the drought in 2010, when there was a major crop failure. When comparing the trend yield for 2010 based on a regression to the actual yields it appears that winter wheat yields only reached $64 \%$ of the expected yield, in soybeans the value was $48 \%$ and in corn only $28 \%$. When looking a production risks this comparison indicates that corn is much more susceptible to unfavourable weather conditions and therefore a riskier crop than the others.

\section{Farming structures}

Given the fact that corn and soybeans are somewhat "non-traditional" in the CBSR and expensive, it can be assumed that structural features of farms may have an impact on their willingness and ability to adopt these new options. Therefore, the subsequent section provides insights into the structure of farms and the importance of corn and soybeans for the different farm types.

Russian statistics distinguish three types of farms: agricultural enterprises, private farms and subsistence farms. Agricultural enterprises are large businesses, usually created on the basis of former collective and Soviet farms, often based on external capital and hired labour use. In many cases, such farms are consolidated in agro holdings. Private farms are usually smaller farms run by one person or with the assistance of family members and primarily based on joint labour input. Finally, a 
third form of agricultural producers is subsistence farms, predominantly producers who sell only their surpluses. This type of farm is widespread in Russia, but in particular relevant in livestock, fruits and vegetables.

Figure 3 indicates that, in corn, agricultural enterprises were able to increase their market share while, in the other crops, private farms expanded their market share. A possible explanation for this is that corn is a rather expensive crop. This fact is subject to further analysis, discussed later. Because access to credit and financial issues have an effect on the shift of crop patterns (Rao, 1989), this point might represent an advantage for agricultural enterprises over other farm types. The main reasons for this are the larger scale of production and diversification of the business (Chetvertakov, 2012). Therefore, farms with sufficient financial liquidity, in particular, are modifying their cropping patterns.

The following results from this section can be highlighted:

(1) CBSR is, indeed, a hot spot of Russian corn and soybean production, both in terms of growth in acreage and in yield improvement.

(2) While corn acreage went up by $17 \%$ and soybeans by almost $33 \%$, wheat acreage increased by only $3.7 \%$.

(3) Regarding the differences in adopting new crops, agricultural enterprises seem to be more involved in corn and soybean production than the other two types of farms.

The next section illustrates the methodologic approaches and related assumptions used for further analysis.

\section{Methods}

Economic theory suggests that growers behave as profit maximizers, provided they operate under market conditions. When looking at cropping patterns and land use this assumption leads to the conclusion that profitability should be higher for those crops which have been able to expand their share in total acreage. Therefore, any attempt to identify the economic drivers for changes in cropping pattern requires a rather detailed set of data regarding input expenditures for individual crops.

Furthermore, the profitability of a certain crop is not necessarily a straight function of cost and revenue generated according to a profit and loss account. There may exist some very important economic drivers in grower's decision making which are non-monetary in nature: (a) rotational effects impacting the subsequent crop positively or negatively, (b) crops may differ in their risk profile (both in production risks and market risks), (c) they may have different peak-times in labour and machinery use and thereby creating different opportunity cost for those production factors and (d) sometimes their liquidity requirements are not the same and growers preferences are impacted differently than what results from an enterprise analysis based on P\&L data suggest (see Albrecht, 2015).

One approach to gathering information regarding economic drivers is the use of official profit and loss figures reported by farms to local authorities in Russia. However, they cannot be used because of the following limitations:

- The level of information is too general - collected data are summarized at a regional level and do not represent single farms.

- These figures entail an inherent risk of being biased, as they were created for reports to tax authorities, possibly creating a strong incentive for producers to lower profits. Therefore, it is most likely that they do not reflect the true economic conditions.

- The absence of non-monetary data in these existing data makes it impossible to evaluate non-budgetary effects of individual crop choices.

In order to generate a realistic picture about economic drivers for growers' decisions it is therefore necessary to get (a) farm and even crop specific information and (b) growers' expertise regarding the importance and the "mode of action" of non-monetary effects associated with individual crops.

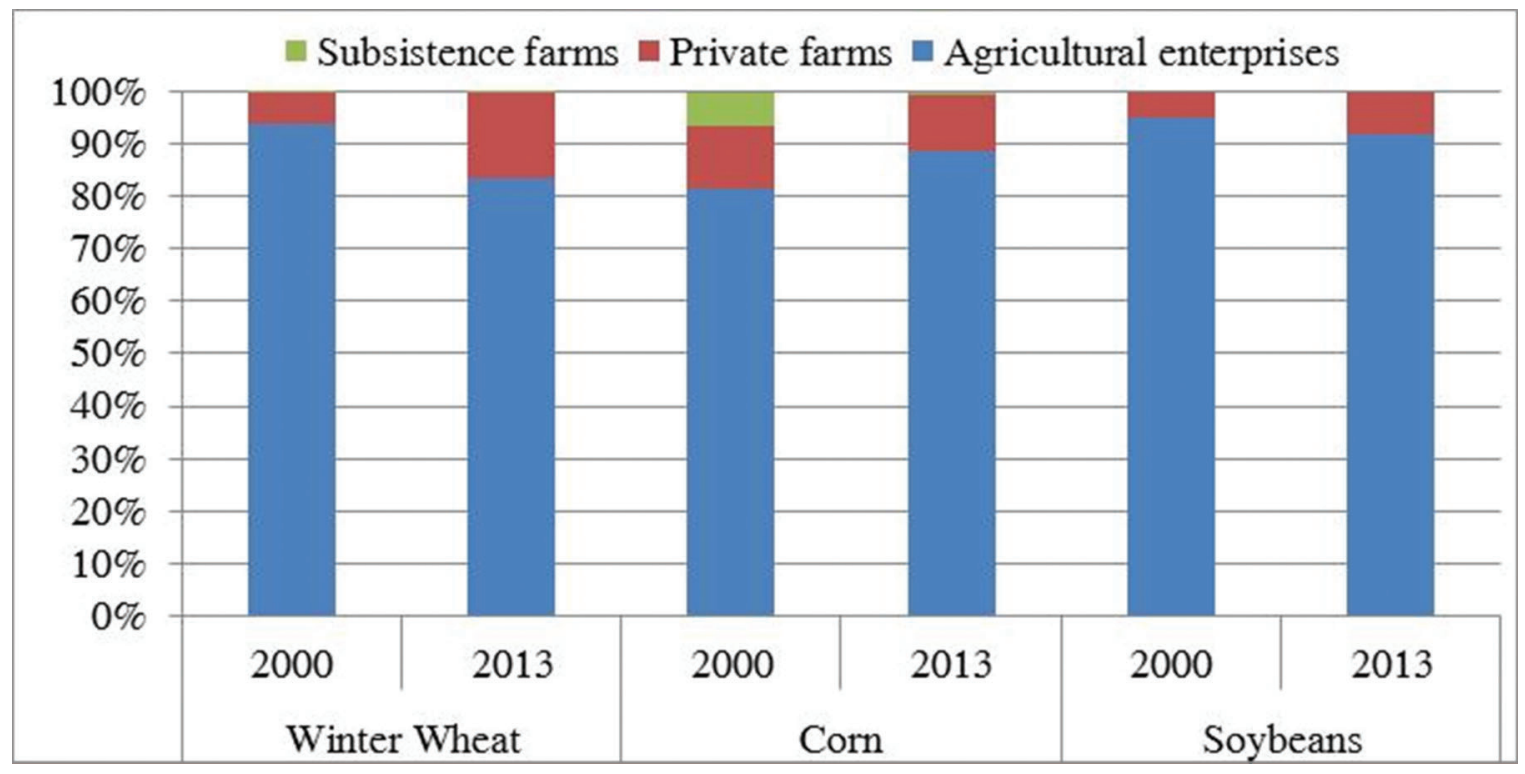

Figure 3: Importance of key crops for Russian farm types Source: UniSIS (2014); own calculations 
When following this approach, the next question arises: Which economic criteria should be used in order to evaluate economics of crop choices? Based on economic theory the "return to land" from a total cost and gross revenue analysis per crop would be the prime option. As of today, this figure is only available directly from agri benchmark data (see agri benchmark, 2015). This data base will be explained in greater detail below. The only shortcoming of this data base is that it does not contain any information on the non-monetary effects.

Given the shortcomings in official economic statistics, in theory the best option would be to collect complete farm and enterprise data on the individual crop level. Given existing budget restrictions for this project this was not a feasible option. Therefore, it seems reasonable to look for additional data sources from a case study in a so-called focus group discussion with a group of growers. The prime goal of this approach will be to (a) doublecheck key economic figures from the agri benchmark data set and (b) to evaluate the non-monetary effects associated with the crop choices. Details of the approach will be developed in more detail below.

\section{Typical farm approach}

Data from typical farms generate in-depth insights regarding the economics of corn and soybean production in Russia. This method is used by agri benchmark Cash Crop, a nonprofit global network of agricultural economists, advisors, producers and specialists in key sectors of crop value chains (agri benchmark, 2014).

The typical farm approach has the following characteristics:

- It represents the origin of a major share of crop output in a given country/region;

- Data are created by using available statistics as much as available;

- Information is usually gathered by local experts and growers;

- It contains data about quantities and prices for outputs, inputs, and production systems;

- The data are available for several years.

The database of agri benchmark contains information about one typical farm in the CBSR that will be used. However, it should be noted that establishing a typical farm in countries such as Russia faces some specific issues:

(1) Potential participants for the establishment of a typical farm are rare. There is a challenge in getting them together for focus group discussions and convincing them to speak openly because there is no culture of economic exchange.

(2) A typical farm cannot be established just with the help of an advisor - which is called a pre-panel typical farm - because they are not accessible. Simply substituting the pre-panel with an additional focusgroup discussion of farm decision-makers probably also would not work as the necessary information is spread over many specialists, who, moreover, often do not know the required information off-hand. Such a focus group discussion would take too long and require too many people.

(3) The less developed expertise of growers and decision makers regarding the economics of their own businesses and the whole sector may cause uncertainty about the quality of the data obtained in the panel process (Walther, 2014).

Against this background the existing typical Russian farm in the agri benchmark data base reflects primarily the situation of one particular farm belonging to a large modernized holding.

\section{Focus group discussion}

Despite the critical framework conditions experienced in previous work (see Walther, 2014) for the purpose of this study a focus group "light" approach has been designed and applied. Rather than trying to accomplish a total cost of production analysis the aim is to (a) generate a detailed variable cost analysis as well as a gross margin comparison for corn, soy and wheat and (b) to identify possible non-monetary effects of respective cropping decisions of growers or decision makers.

In order to do so one of the authors participated in the annual meeting of soybean growers of the Voronezh region in which the offer to more discuss economics of corn and soybean production was made to the participants. The resulting group consisted of five farmers, growing all three crops: wheat, corn and soybeans. All participants are responsible for their own agricultural business or are executive managers. Representatives of agroholdings did not attend and the participants therefore represented relatively small-scale farming for Russian conditions (fewer than 10,000 ha per farm).

The focus group discussion took place on November 12, 2014 in Voronezh. It was divided in two parts. The aim of the first part was creating an interest for crop economics comparison and generating a trustful and constructive atmosphere. For this part, the author presented analysis about the respective crop economics of a typical agri benchmark farm in the USA in North Dakota, where there is a lively competition between wheat and corn.

The second part of the meeting was devoted to the topic of typical production systems for corn, wheat and soybeans in the Voronezh region. In the course of a joint discussion among participants and the moderator a spreadsheet with all key cost elements as well as yield and product prices was completed (see Table 2). Even though there is not a culture of exchanging economic data among Russian growers a rather lively and open debate took place; it lasted for about 1 hour. This method made it possible to achieve the following:

(1) With a group of growers, it is easier to compare the whole range of figures and to find a representative type of operation/management for the given natural and economic framework conditions.

(2) Individual farmers might be reluctant to share sensitive individual economic data such as costs of production. Since the aim was to identify typical data for the region this obstacle could be overcome.

Given the different background of participants compared to the existing typical agri benchmark farm, which belongs to a large and relatively well equipped holding, it should be expected that results will be different.

In the next section, the results from the application of aforementioned methods will be presented. 
Table 2: Typical direct cost, yields, prices and gross margin of wheat, corn, soybeans

\begin{tabular}{|c|c|c|c|c|}
\hline Key elements & Units & Wheat & Corn & Soybeans \\
\hline $\begin{array}{l}\text { Seeds } \\
\text { NPK cost } \\
\text { Amount of pure nutrients applied } \\
\text { Herbicides } \\
\text { Other crop protection } \\
\text { Drying } \\
\text { Yield } \\
\text { Market price }\end{array}$ & $\begin{array}{l}\text { USD/ha } \\
\text { USD/ha } \\
\mathrm{kg} / \mathrm{ha} \\
\text { USD/ha } \\
\text { USD/ha } \\
\text { USD/ha } \\
\text { MT/ha } \\
\text { USD/t }\end{array}$ & $\begin{array}{c}69.9^{*} \\
71.3 \\
65 \text { N, } 10 \mathrm{P} \\
34.2 \\
28.5 \\
\\
4.0 \\
203.5\end{array}$ & $\begin{array}{c}114.0 \\
99.8 \\
94.5 \mathrm{~N}, 13 \mathrm{P} \\
42.8 \\
14.3 \\
147.2 \\
6.5 \\
169.6\end{array}$ & $\begin{array}{c}54.7^{\star} \\
34.2 \\
20 \mathrm{~N}, 12 \mathrm{P}, 12 \mathrm{~K} \\
34.2 \\
8.6 \\
\\
1.8 \\
418.3\end{array}$ \\
\hline $\begin{array}{l}\text { Direct cost } \\
\text { Revenue } \\
\text { Gross margin }\end{array}$ & $\begin{array}{l}\text { USD/ha } \\
\text { USD/ha } \\
\text { USD/ha }\end{array}$ & $\begin{array}{l}203.9 \\
814 \\
610.1\end{array}$ & $\begin{array}{r}418.1 \\
1102.4 \\
684.3\end{array}$ & $\begin{array}{l}131.7 \\
752.9 \\
621.2\end{array}$ \\
\hline
\end{tabular}

* seed cost count $1 / 3$ seeds as commercial and $2 / 3$ as farm saved

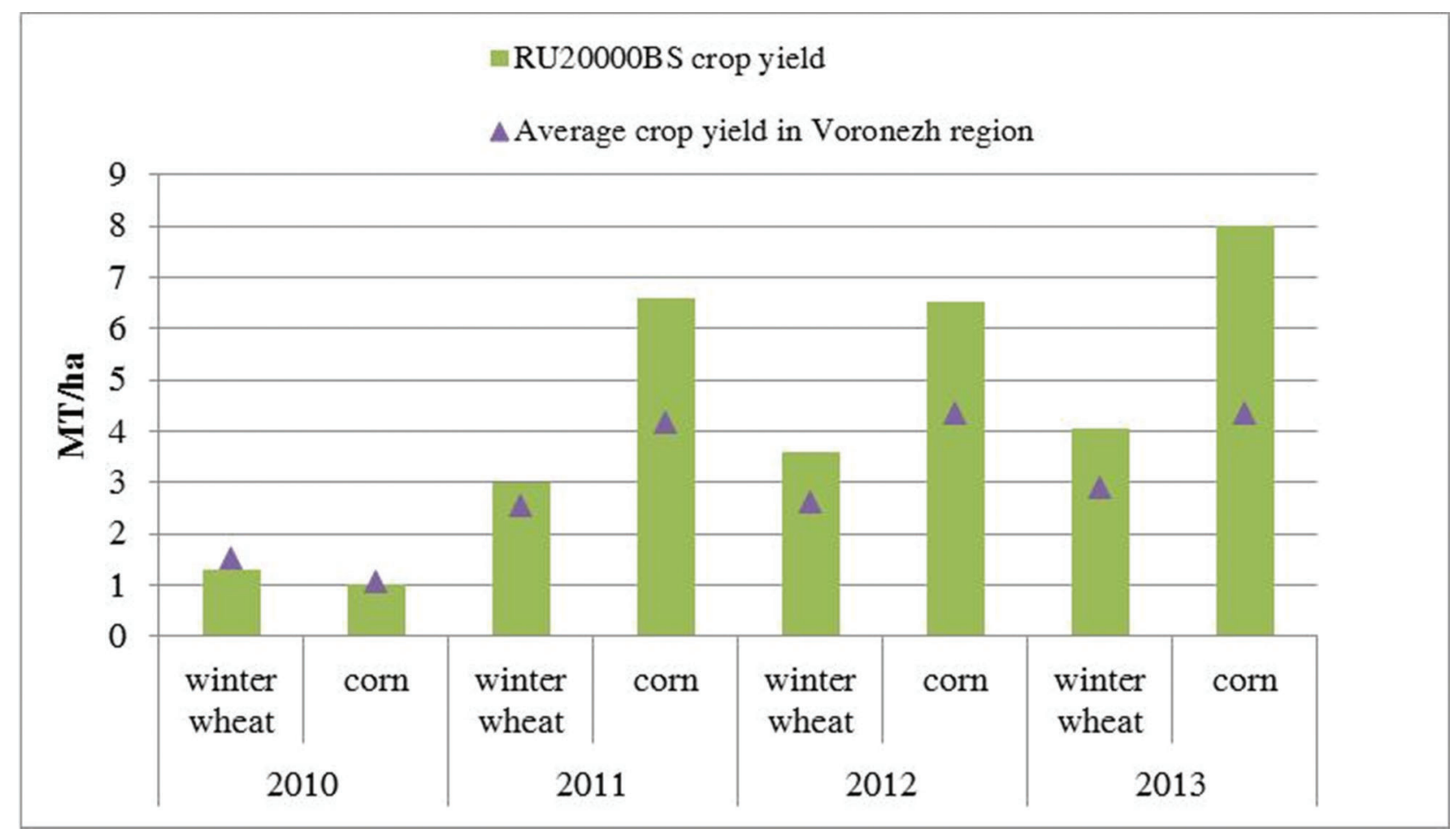

Figure 4: Winter wheat and corn yield for RU20000BS and the average in Voronezh region Source: own calculations based on agri benchmark database and UniSIS (2014)

\section{Economics And Farming Conditions Of The Major CBSR Arable Crops}

As already mentioned, the most important crop in the CBSR is winter wheat. This is the only crop grown on all analysed farms and will therefore be used as a benchmark for the economics of corn and soybeans

\section{Typical farm}

The review of economic indicators starts with a typical agri benchmark farm (abbreviated to RU20000BS). It has 20,000 hectares of arable land. Crops rotated there are winter wheat, spring wheat, winter rye, corn, spring barley, peas, and sunflower. Unfortunately, this farm does not grow soybeans. Key indicators for the analysis are shown in Figures 4 and 5.

In order to understand the performance of the agri benchmark farm and its position relative to its regional peers, Figure 4 shows the wheat and corn yields for this farm and the regional average. On the one hand it is remarkable that regional averages are significantly below the farm achievements. However, when looking at the subsequent figures from the focus group discussion (see Table 2) it appears that also under these circumstances actual yields are significantly higher than the regional averages based on official statistics. The poor yield in both data sets in 2010 can be explained by a severe drought. It should be noted that the yield of corn under these adverse conditions was less than the yield of winter wheat. In the other three years' corn yields were almost twice as high as wheat yields.

The total cost depicted in Figure 5 includes direct costs (seeds, fertilizers and crop protection) and operating costs (labour, machinery, contractor and diesel), building cost, land, and miscellaneous cost. The market revenue was calculated as gross yield multiplied by ex-farm prices. The difference between the market revenue and the total cost is the profit.

Due to the high cost and lower market revenue of corn compared with wheat, the unfavourable weather 


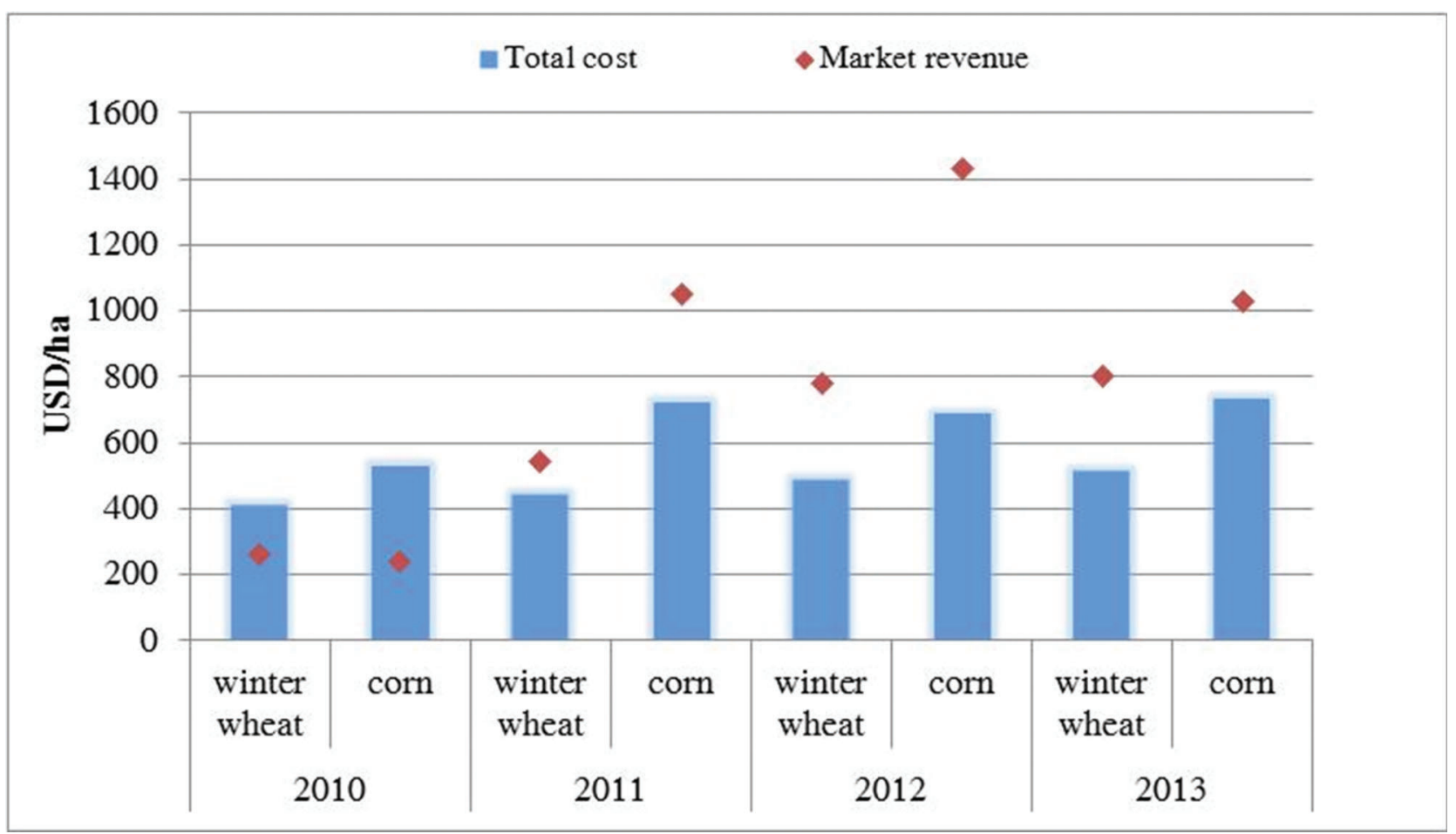

Figure 5: Winter wheat, corn revenue and total cost for RU20000BS Source: agri benchmark database and own calculations

conditions in 2010 caused much higher economic losses for corn (287 USD/ha) than for wheat (148 USD/ha). However, for the other three years in this comparison, the profit per hectare of corn was higher than per hectare of wheat: $234 \mathrm{USD} /$ ha in 2011, $452 \mathrm{USD} / \mathrm{ha}$ in 2012 and $7 \mathrm{USD} / \mathrm{ha}$ in 2013. The reason for the significant decline in the advantage in profit of corn over wheat was a sharp reduction of relative corn prices in 2013 . However, all in all one can conclude that there is good reason to assume that in recent years' corn tended to be more profitable than wheat and thereby the economics were indeed a key driver for the rapid expansion of corn acreage in the CBSR.

\section{The focus group discussion}

The focus group discussion resulted in a compilation of direct cost, yields, and prices for selected crops, as presented in Table 2. To understand the method of calculation, some details have to be explained. Costs and prices are given on a factual basis for 2014; whereas yield figures are based on multi-annual expectation of growers participating in the focus group discussion (not factual).

In 2014, the Russian rubble experienced a significant devaluation, which caused a conversion issue. Of course, in an ideal situation one would use the exchange rate for the day the transactions took place, but these dates are not available. To minimize inaccuracies and to present a most realistic picture, an average exchange rate to the US dollar was used. For costs, the average exchange rate was calculated from January 1, 2014 to May 31, 2014, the time span during which the bulk of input purchases takes place. For output prices, the exchange rate was calculated for the period October 29, 2014 to November 11, 2014, the two weeks prior to the focus group discussion. However, it should be noted that any imperfection of the approach does not affect the comparison between the different crops.
Seed cost in the table result from one third of wheat and soybeans seed being commercially bought while the remainder is farm saved seeds. This reflects the actual practice of the growers participating in this focus group discussion. The figures presented in Table 2 therefore are comprised of the two sources: farm saved seed where valued by its opportunity cost; the price of commercial grains and commercial seed.

The gross margin is calculated on the basis of direct cost (which is the sum of seed, fertilizers, herbicides, other pesticides, and drying of corn) and revenue (calculated as market price multiplied by yield). It appears that corn generated the highest margin, USD 74 more than wheat. Growing soybeans yields USD 11 more than wheat. When looking at the details for cost in corn it can be seen that the majority of direct cost is drying cost. This figure indicates an elevator charge for this service for a corn crop with an initial moisture content of $25 \%$; the elevator's profit is included. Given the lack of onfarm drying capacities this figure represents the current economic conditions for most growers in the region.

However, in the long run this picture might change with on-farm investments in drying equipment. Therefore, we also calculated the corn gross margin with on-farm drying. Since there is no data available for on-farm drying cost in Russia a respective calculation from an official crop budget from North Dakota (USA) (Crop budgets, 2014) is used as a first approximation. This source estimates the on-farm drying cost (fuel, depreciation, finance, labour) at about USD 70 per ha for the corn conditions in the table. When using this figure for the calculation instead of the service fees charged by elevators, the advantage of corn over wheat margin increases to approximately USD 150/ha. Such an increase would most likely strengthen the trend to produce corn. Another factor playing in favour of corn is the recent decline in oil prices. Due to the massive 
drop in global, and subsequently Russian oil prices, drying cost should have gone down significantly as well. Therefore, the competitiveness of corn has increased even more.

However, gross margins are not the only factor considered by farmers. Different crops have different effects on subsequent crops, they have different risk profiles and they differ regarding labour and machinery use during peak times. To identify properties of the analysed crops that are not reflected in the crop budget, the group was asked for effects that have an influence on their decisions. There was also an open question for additional effects that could have been missed by the authors.

Answers revealed that farmers do not consider special risks of individual crops; all crops are assumed to be risky. Moreover, neither agronomic complexity nor other issues (marketing, timing, trusted partners) influence the crop decision. An additional economic stimulus that can influence farmers' crop decision is subsidies. According to the farmers, there can be more subsidies for one crop than for another, but the differences are rather insignificant and usually are not taken into consideration when taking cropping decisions. When asked about their future plans regarding cropping patterns, none of the participating farmers had a specific inclination to increase the corn ratio in their rotations. The main reason: adding more corn acreage would imply the need to make additional investments in equipment for seeding, harvesting and storage. Regarding soybeans, some farmers expressed an interest in increase acreage. This willingness in favour of soy can be interpreted as a result of a smaller threshold between wheat and soybeans in comparison to corn.

\section{Conclusions}

Economic analysis of farm data suggests that the strong growth in corn and soybean production in the CBSR in Russia is indeed driven by rather high profitability when compared to wheat. An advantage of more than $100 \mathrm{USD} / \mathrm{ha}$ in profit or gross margin is considered to be a very strong incentive to shift cropping patterns. The outcome from the focus group discussion reinforced the results generated through the existing typical agri benchmark farm, even though as expected actual data were different.

Given the high importance of drying cost and the fact that currently many producers in the CBSR rely on rather expensive services from elevators there is room for an additional increase in corn margins compared to wheat. Of course this is subject to significant additional investments at the farm level, which are subject to the availability of loans and interest rates. Taking into account trends in yield for corn vs. wheat in the CBSR it has to be assumed that in future the fundamentals will develop even more in favour of corn.

Even though theoretical considerations do suggest a higher economic risk to produce corn compared to wheat, growers participating in the focus group discussion were not concerned about this issue. They also did not mention any rotational effects or other nonmonetary effects associated with these crops. Whether this means those effects do not exist at all in the CBSR or whether growers participating in the focus group discussion were not yet as sophisticated operators as their colleagues in the West remains to be seen.
Despite these results the growers participating in the focus group discussion were not considering significantly expanding their acreage seeded to corn but were eager to increase their soybean acreage. When looking at increasing corn, they were concerned about the associated need for additional investments needed in equipment. Given high interest rates this does reflect the current situation but of course it does not exclude a mid- to long term shift. It also does not mean that new growers will not start to produce corn.

With regard to the methodology it turns out that in principle the globally applied focus group approach did work in Russia as well. However, it should be noted that this first test of the concept was done with a less sophisticated version by only asking for gross margin figures.

\section{About the authors}

Sergey Chetvertakov is a PhD student at Georg-AugustUniversität Göttingen and works in the agri benchmark Cash Crop Team (Thünen Institute, Braunschweig, Germany)

Dr. Yelto Zimmer is Head of agri benchmark Cash Crop Team and Manager of the working group "arable farming economics" (Thünen Institute, Braunschweig, Germany)

\section{REFERENCES}

agri benchmark (2014). Who we are. [online] Available at: < http://www.agribenchmark.org/agri\%20benchmark/whowe-are.html $>$ [Accessed 12 May 2014].

agri benchmark (2015). Home page. [online] Available at: <http:// www.agribenchmark.org/home.html $>$ [Accessed 12 May 2014].

Albrecht, R. (2015). Ein Ansatz zur Abschätzung der interregionalen Wettbewerbsfähigkeit der Zuckerrübenproduktion - am Beispiel ausgewählter europäischer Regionen. Braunschweig: Thünen-Institut, Bundesforschungsinstitut für Ländliche Räume, Wald und Fischerei, 238 p, Thünen Rep 24.

ASVR (2014). История административно-территориального деления воронежского края. [online] Archival Service of the Voronezh Region. Available at: < http://arsvo.ru/arkhivnayasluzhba/istoriya-administrativno-territorialnogo-deleniyavoronezhskogo-kraya-3-ot-tsentr\#_edn1 > [Accessed 13 May 2014].

Chetvertakov, S.I. (2012). Investigation and clarification of concepts, motives and principles of organization of integrated agro-industrial groups Organizer of Production, 54(3), 15-19.

Climate (2014). Погода и климат. [online] Available at: < http://www.pogodaiklimat.ru > [Accessed 13 May 2014].

Crop budgets (2014). Projected 2014 Crop Budgets: South Valley North Dakota. [online] Farm Management. Available at: <http://www.ag.ndsu.edu/farmmanagement/documents/ sv2014 $>$ [Accessed 22 May 2015].

Doran, T. (2014). Corn, soybean export locomotive rolls on. [online] Agrinews. Available at: < http://agrinews-pubs.com/ Content/News/Markets/Article/Corn--soybean-export-loco motive-rolls-on-/8/26/10161 > [Accessed 9 May 2014].

Liefert, W.M., and Liefert, O. (2012). Russian Agriculture during Transition: Performance, Global Impact, and Outlook. Applied Economic Perspectives and Policy. 34(1), 37-75. DOI: 10.1093/ Aepp/Ppr046.

Munro, E. (2013). Strong corn competition from Russia, Ukraine. [online] Corn and Soybean Digest. Available at: < http://cornandsoybeandigest.com/issues/strong-corn-competition-russia-ukraine $>$ [Accessed 9 May 2014].

Rao, J.M. (1989). Agricultural supply response: A survey. Agricultural Economics, 3(1), 1-22. DOI: 10.1016/0169-5150(89)90036-4. 
UniSIS (2014). Unified Interdepartmental Statistical Information System of the Russian Federation [Federal State Statistics Service $>$ Agriculture, hunting and forestry] [online]. Available through: < http://www.fedstat.ru > [Accessed 12 May 2014].

Vorotnikov, V. (2012). Russia is producing more soybeans and corn. [online] AllAboutFeed. Available at: <http://www.allaboutfeed. net/Nutrition/Raw-Materials/2012/3/Russia-is-producing-moresoybeans-and-corn-AAF012875W > [Accessed 9 May 2014].
Walther, S. (2014). Determinants of competitiveness of agriholdings and independent farms in Ukrainian arable production. Braunschweig: Johann Heinrich von Thünen-Institut, 230 p, Thünen Rep 15.

Wright, C.K., and Wimberly, M.C. (2013). Recent land use change in the Western Corn Belt threatens grasslands and wetlands. Proceedings of the National Academy of Sciences, 110(10), 4134-4139. DOI: 10.1073/pnas. 1215404110. 


\title{
CROP CHOICE DECISION UNDER UNCERTAINTY: A CASE STUDY IN RUSSIA
}

\author{
Chetvertakov Sergey \\ Institute of Farm Economics, Thunen-Institut, Braunschweig, Germany \\ E-mail: chetvertakovsergey@gmail.com
}

\begin{abstract}
The recent expansion in corn and soybean acreage in Russia raises interest regarding the reasons behind it. A previous study by the author revealed greater profitability of corn and soybeans than the most popular crop - winter wheat. However, although shift to a cornsoybean rotation or even continuous corn is agronomically feasible, many farmers are not willing to take the related risks. Hence, the goal of this article is to derive the optimal crop portfolio accounting for relative risk aversion coefficients of farmers. On the basis of the stochastic simulation method, a new technique for risk optimization was developed. The findings indicate crop diversification is a good method to mitigate risk under Russian conditions. Only farmers preferring risk would switch to corn as a monocrop rotation.
\end{abstract}

\section{KEY WORDS}

Stochastic simulation, certainty equivalents, optimization, risk, Russia.

The agricultural sector in the Russian Federation has recovered since the beginning of the 2000s, following a significant drop in development during the 1990s. Unbalanced segments of Russian agriculture, inherited from the Soviet era, face the market and compete with other sectors of economy for investments and with foreign companies for consumers. Growing world demand and market opportunities have raised some interest in growing corn and soybeans. Rapid expansion of these crops raised concerns in the business world (Vorotnikov, 2012; Munro, 2013; Doran, 2014), but was ignored by scientists.

A prior study by the author (Chetvertakov, 2015) revealed a new hot spot of corn and soybean production - the Central Black-Soil Region (CBSR). Results of a survey proved the hypothesis that corn and soybeans are more profitable than wheat. In fact, based on accounting data alone, one would conclude that growers should move to a straight corn-soy rotation wherever agronomically feasible. However, average profitability is not the only factor in decision making regarding crop choice. Given uncertainty regarding both prices and yields, risk may impact growers' decisions. Therefore, profit maximization, the main goal of any entrepreneur, cannot be exploited uniformly. In the real world, decision makers consider both expected return and related risk in light of their personal level of risk aversion. According to Hazell (1971) and Hazell et al. (1986), disregard of risk as a factor of production sometimes leads to unacceptable results.

Hence, in determining their optimal crop portfolio, farmers should include different crop risk profiles in their decision. "Optimal" can be defined as the best equilibrium between return and risk, accounting for personal risk attitude. Such decisions usually are taken based on intuitive risk assessment and significantly depend on the personal experience of a farmer and unique features of the operation. However, recently developed scientific methods and software afford the ability to estimate different portfolio sets in an objective way and calculate possible returns in relation to observable risk.

This study aims to calculate the optimal crop portfolio in CBSR relative to a range of risk aversion for one future marketing year as a proxy: 2015-2016. This should answer a question: At what coefficient of relative risk aversion are farmers willing to increase share of the relatively new crops, corn and soybeans? Stochastic simulation is applied as a method of research.

This paper is organized as follows: The first section reviews the literature. The second section discusses the methods used in the paper. The results are outlined in the third section and the last summarizes the main findings and provides some conclusions. 


\section{LITERATURE REVIEW}

Early applied methods for risk analysis, such as stochastic efficiency, could not provide strong discriminatory power and Meyer (1977) introduced stochastic dominance with respect to a function. However, this method was overtaken by stochastic efficiency with respect to a function (Hardaker et al., 2004) and is the most powerful method to compare risky alternatives up to this time.

The concept of Certainty Equivalents (CE), exploited in the method, demands determination of risk aversion. Absolute risk aversion, defined by Pratt (1964) and Arrow (1965), lacks comparison power, because it represents risk expressed relative to the amount of risky outcome. This drawback can be overcome by relative risk aversion, which affords comparison of alternatives with different payoffs. Classification of relative risk aversion was introduced by Anderson and Dillon (1992).

Risk aversion expresses the utility function of the decision maker. For general problems, when the utility function of the decision maker is unknown, scientists apply the most popular utility functions: negative exponential, logarithmic and power (Ladanyi, 2008). However, the literature includes a great variety of functions with different features, described by Bell (1988), Saha (1993), Nakamura (1996) and Schumann et al. (2004).

The most prominent overview of agricultural risk management is provided by Hardaker et al. (2004). In their book, as in many other papers (Chavas and Holt, 1990, Hardaker et al., 2004, and Richardson and Outlaw, 2007), selection of the optimal decision stems from predetermined alternatives, which can be improved by the application of market and production risks as stochastic processes.

While production planning under uncertainty has been widely researched, there is still a gap in optimization calculation under uncertainty (Mula et al., 2006). For instance, Osaki and Batalha (2014) discuss agricultural production optimization issues under risk, but findings reflect options with regard only to deviations from the mean value as a measure of risk. According to Capolei et al. (2015), such a method has two main drawbacks: It is not sensitive to the profit shape distribution and it is symmetric and therefore penalizes higher and lower profits equally. Based on the foregoing, techniques for production optimization under uncertainty require further improvement.

\section{MATERIAL AND METHODS}

Designing the model. The main purpose of the model is derivation of the optimal crop allocation. The key output variable in this case is the net present value ${ }^{1}$ of the return to land. Therefore, the objective function will be Eq. (1)

$$
\max z=\sum_{i=1}^{n} p_{i} Y_{i} A_{i} \quad c_{i} A_{i}
$$

where $\mathrm{z}$ is return to land, $\mathrm{n}$ is the number of crops produced by a farm, $\mathrm{p}$ is the price of the $\mathrm{i}$ product, $Y_{i}$ is yield per ha of the respective crop, $A_{i}$ corresponds the crop acreage and $c_{i}$ is the cost per ha.

The aforementioned equation can be applied in linear programming, but it does not incorporate the risk issue and, for stochastic analysis purposes, the concept of CE fits better as the optimum can be found with the utility function application. This paper exploits the exponential utility function (Eq. 2) proposed by Hardaker, Richardson et al. (2004), which assumes constant relative risk aversion:

$$
C E\left(w, r_{a}(w)\right)=\ln \left\{\left(\frac{1}{n} \sum_{i}^{n} \exp \left(r_{a}(w) w_{i}\right)\right)^{-1 / r_{a}(w)}\right\}
$$

where $r_{a}(w)$ is an absolute risk aversion with respect to wealth.

\footnotetext{
${ }^{1}$ Return to land expressed in the net present value enables comparison and calculation of returns to land for different years
} 
In this paper, wealth $(w)$ and return to land $(z)$ are assumed to be equal. For the purpose of convenience, the absolute risk aversion $r_{a}$ will be substituted by the relative risk aversion $r_{r}$ and expected money value $E$ as $r_{a}=\frac{r_{r}}{E}$ (Pratt, 1964; Arrow, 1965). This expression is preferable as relative risk aversion is not sensitive to units of outcome measurement and the results therefore are directly comparable (Meyer and Meyer, 2005).

It follows from Eq. (1) that the model requires cost, yield and price information. In this study, the author focuses only on the main cash crops of the CBSR: corn, spring barley, spring and winter wheat, sunflowers and soybeans. In 2014 , these crops covered $84 \%$ of all land planted to cash crops. Sugarbeet, which also is an important cash crop for the region (occupied $7 \%$ of cash crop acreage), is not included because this crop's feasibility is highly correlated with distance to a processing facility and, moreover, this sector is highly monopolized.

The type of necessary data depends on the nature of the analysis; calculations can be done in a retrospective or prospective manner. Retrospectivity assumes the search for the best option is based solely on historical data and the result also will be the best choice for the future. In other words, the calculation indicates the best option and its outcome in the past and assumes following this track in a future will provide the maximum profit with the lowest risk. The prospective calculation, on the other hand, assumes some variables will not have an identical distribution in the future and applies expected changes. In this research, prices and costs ignore the historical values and can be adjusted in the forecast. Yield is assumed to have the same distribution as in the past. Both options are outlined in the paper.

For convenience, further explanation of the model's construction is divided by blocks.

Block of costs. Cost data are obtained from the agri benchmark typical farm in the Voronezh region (part of the CBSR). Data from typical farms generate in-depth insights regarding the economics of the main crops produced in Russia. This method is used by agri benchmark Cash Crop, a non-profit global network of agricultural economists, advisors, producers and specialists in key sectors of crop value chains (agri benchmark, 2014).

Official yield statistics show changes in the production pattern in 2004, when corn and soybeans began to expand. Therefore, the data should embrace the years of 2004-2014. Cost data of the typical farm in the agri benchmark database were collected for 2009-2014. Costs for missed years are calculated by deflation of 2009 costs.

The aforementioned cost calculation is applied in the retrospective calculation. For the prospective calculation, the 2014 data are inflated according to the price change in agricultural inputs in 2015. The relative price change was provided by the Institute for Agricultural Market Studies in Russia.

There is one more issue linked with the cost data: the need to calculate fixed and variable costs separately. Moreover, such costs may vary relative to a crop's share in a rotation and a significant deviation from the original ratio can occur because of the lack of labor and equipment. Nevertheless, Russian agriculture in this region has a great supply of contractors. The climatic conditions in the western part of Russia allow such contractors to begin seasonal work in the south and work their way north to the CBSR and beyond, working greater acreage than a single farm.

The cost of contractors is comparable to farmers' own costs and in the analysis, they are assumed to be identical. Therefore, costs consist of two variable elements: the direct input cost per ha (seeds, fertilizers and pesticides) and operating cost per ha (labor, machinery and diesel and other energy cost). Other on-farm costs not related to crops are not included as they do not play a role in the net return comparison between crops.

Another calculation method was applied to soybeans. The sample typical farm does not grow this crop so an average production cost was taken from a survey conducted by the author (Chetvertakov, 2015). For retrospective analysis, cost data were deflated to derive figures for the entire period of calculation. For the prospective analysis, soybean production costs are calculated in the same manner as other crops.

Block of yields. Yield data for the representative typical farm do not exist for a long period (only 2009-2014, as mentioned earlier) and the study uses official statistics at the 
farm's county level (GKS regional 2015). The county statistics present the most detailed level of official data and better reflect variability in yields than statistics at a regional or national level.

Retrospective analysis applies empirical yield data. For the prospective analysis, yield is treated stochastically and is subjected to Monte Carlo simulation. To achieve a better predictability of yield distribution, de-trending was considered, using residuals after detrending in the simulation. However, sparse data do not allow such procedure. Therefore, all yields are simulated according to the historical data.

Block of prices. Retrospective analysis applies historical prices. For 2009-2014, the prices of the typical farm are applied. For the rest of the period, monthly prices were obtained from the official statistics on the regional level (UniSIS, 2015) and calculated as the average for the marketing year. Prices for soybeans were defined by official statistics only.

Determination of prices for the prospective analysis is one of the most challenging aspects of the analysis. Market risks play a significant role in agriculture and are difficult to predict. This risk may be mitigated by insurance, which is commonly used in much of the world (Vilhelm, 2011). However, the market for insurance is underdeveloped in Russia: In 2014 , only $17.7 \%$ of the total acreage was insured (NAAI, 2015). Hedging instruments also are not common in Russia (e.g., a futures market does not exist in the state). Therefore, most farmers rely on the spot market. Adding to price uncertainty are the significant depreciation of the national currency since 2014 and the establishment of export fees for wheat (Gov, 2015).

Given such factors, expert estimation of future prices is the best proxy. For this task, two experts were asked to make projections of the minimum, maximum and the most probable prices of selected crops (one expert provided expertise with regard to small grains and corn and the other for oilseeds) for the 2015-2016 agricultural year. This evaluation was used to derive PERT distribution, where prices are assumed to be a stochastic value.

Calculation. All monetary data are expressed in the national currency, the ruble. The rationale for this decision is based on two factors:

a) All costs and cash payments in Russia are implemented in rubles. Note, however, that given high fluctuations of exchange rates and the time lag between expenditure on inputs and receipt of proceeds, calculations will not reflect a true market picture.

b) Wheat export fees also are measured in local currency and incorporate exchange rate risk.

Conversion of monetary values to other currencies is possible, but would require additional complicated adjustments.

The acreage values are rounded with precision of 10 ha. This provides better handling of figures and does not lead to a considerable change in the results.

Retrospective maximization. Multiplication of yields per/ha and prices/ton for each year gives the revenues per ha. Deducting costs provides the net return per ha of selected crops for 11 years: 2004-2014. Then, to calculate crop portfolio outcome, the net return/ha of every crop of each year was multiplied by the acreage (initially assigned 10 hectares each) and net return of all crops was summarized in the farm net return. All return values were converted to the net present value of 2014.

The next step involves the calculation of CE according to equation 2. The best crop portfolio assumes the highest CE. This task can be performed by the Solver Add-in for Microsoft Excel by changing acreages for each crop. The maximization task is the subject for constraints:

1) $A_{i} \geq 0 \quad i(1, \ldots, n)$

2) $\sum_{i=1}^{n} A_{i} \leq 20000 \quad i(1, \ldots, n)$

3) $A_{\text {small grains }} \leq 60 \% \times \sum_{i=1}^{n} A_{i}$

4) $A_{\text {sunflower }} \leq 14.3 \% \times \sum_{i=1}^{n} A_{i}$

The first constraint is non-negative acreage values. The second is that total acreage cannot exceed 20,000 ha (total cropland of the typical farm). The third and fourth constraints are agronomical rigid rules for this area, which can be violated for a short-term, but should be respected for a long-term production. 
According to the classification of the degree of risk aversion developed by Anderson and Dillon (1992), the relative risk aversion is varied from 0 to 4 , reflecting gradation from risk neutrality to extremely risk averse. The author also applies negative risk aversion coefficients up to -4 to reflect risk lovers. Changing the relative risk aversion coefficient provides the most profitable crop portfolio according to risk.

Prospective maximization. Prospective maximization assumes stochastic variability of yield and prices, but does not cancel their dependence. Therefore, in the first stage, historical yields and prices across all crops were estimated with regard to correlations. For this task we can apply copula correlation with the help of ModelRisk by Vose Software. Because of the sparse data, it is difficult to judge the form of the correlation. Hence, to reflect the most general, linear form of correlation, a multi-normal copula is employed here.

Switching from the empirical data to the Monte Carlo simulation demands distribution estimation. For yields, empirical distribution was fitted. Prices, as was mentioned in the block of price data, take the PERT distribution according to the expert estimation. Simulation has been performed according to distributions and assigned copulas with 30,000 samples in Microsoft Excel with the ModelRisk add-in. Simulated values were validated by correlation test: The correlation matrix of simulated values was compared with the correlation matrix of the original data (performed with Simetar add-in for Microsoft Excel). Calculated Student's ttest statistics indicate high validity of the data and estimated coefficients do not exceed critical values, with the confidence level equal to $99.9 \%$. A comparison test of two data series (only for empirical and simulated yields) failed to reject that the mean vectors are equal.

Multiplication of simulated yields and prices provides the revenues and subtraction of costs (derivation explained earlier) gives net return distribution. Search for a crop rotation with the highest CE follows the same pattern as for the retrospective maximization. The only difference is that the data represent not the historical values, but simulated ones.

\section{RESULTS OF RESEARCH}

Retrospective maximization. The application of the model reveals the optimal crop acreage allocation according to the relative risk aversion coefficients in table 1 . Risk-seeking farmers would choose corn as a monocrop as it provides potentially the highest maximum net return, equal to $764 \mathrm{mln}$. rubles per farm (with 20,000 ha) or 38.2 thousand rubles per ha (net present value of 2014). With the highest net return, such a farmer also would be subject to the greatest losses $-213 \mathrm{mln}$. rubles per farm (10,650 rubles per ha).

The optimal decision for a risk-neutral person would be to distribute $14.3 \%$ of acreage to sunflower, which is the limitation objective. More risk-averse farmers should distribute acreage also to spring barley and winter wheat. Farmers with the relative risk aversion equal to 1 should consider growing five out of six investigated crops. Producers with higher risk aversion would increase acreage of soybeans and winter wheat and decrease acreage of corn and spring barley, with the extremely risk averse reaching zero. Spring wheat would not be included in any crop portfolio.

The differences in crop portfolio sets are plotted in the Fig. 1. The mean changes slightly across variants, but minimum and maximum net return lines are seeking each other with increasing risk aversion. Certainty equivalent comes closer to the maximum return for risk lovers and vice versa for risk-avoiding people and intersects the mean line at zero (risk neutral).

Prospective maximization. Results of the CE maximization for 2015-2016 on the basis of prospective calculations have lower variability. Similar to the retrospective calculation, risk lovers would grow only corn (table 2) and expect average net return $163 \mathrm{mln}$. rubles with maximum and minimum net returns per farm of 700 and -447 mln. rubles. However, farmers with relative risk-aversion coefficients in a range equal to -0.5 to 0.5 would increase winter wheat and sunflower acreages to higher limits, leading to a considerable decrease in possible losses, namely to $-199 \mathrm{mln}$. rubles per farm. At the same time, probability of having a negative net return drops from 0.36 to 0.1 (Appendix 2). Farmers with higher risk aversion would switch to soybeans instead of corn. Crop farmers with a relative risk aversion equal to 
2 and higher would keep winter wheat and sunflowers on the higher limits and grow soybeans on residual acreage. That mix potentially can provide the maximum net return of $668 \mathrm{mln}$. rubles and $133 \mathrm{mln}$. rubles of losses with the probability of getting a negative net return at 0.09 . Spring wheat and barley should not be grown across all risk-aversion options in order to reach the optimal portfolio.

In general, indicators in the prospective analysis follow the same pattern as the retrospective one (Fig. 2). However, the minimum and the maximum net return lines have slightly different forms: In the retrospective analysis, the maximum net return curved more across relative risk-aversion coefficients than the minimum net return. It is the other way around in the prospective analysis. This means that in the first variant of calculations, risk reduction resulted in a more significant downturn in potential maximum net return than potential negative net return mitigation. In the second variant of analysis, diminishment of potential losses to reduce risk was accompanied by only a slight decline in maximum net return.

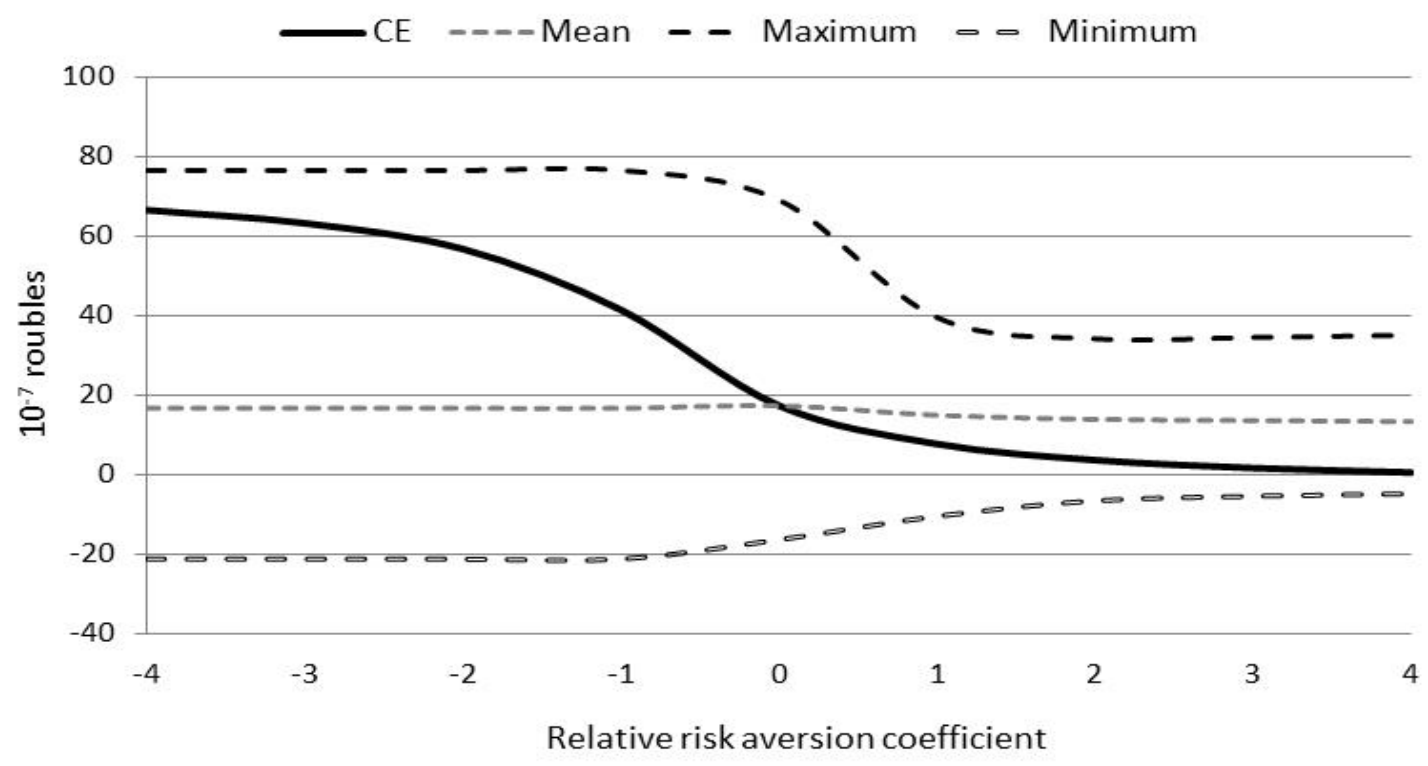

Figure 1 - Optimum net return (retrospective basis) frontier with respect to the risk aversion

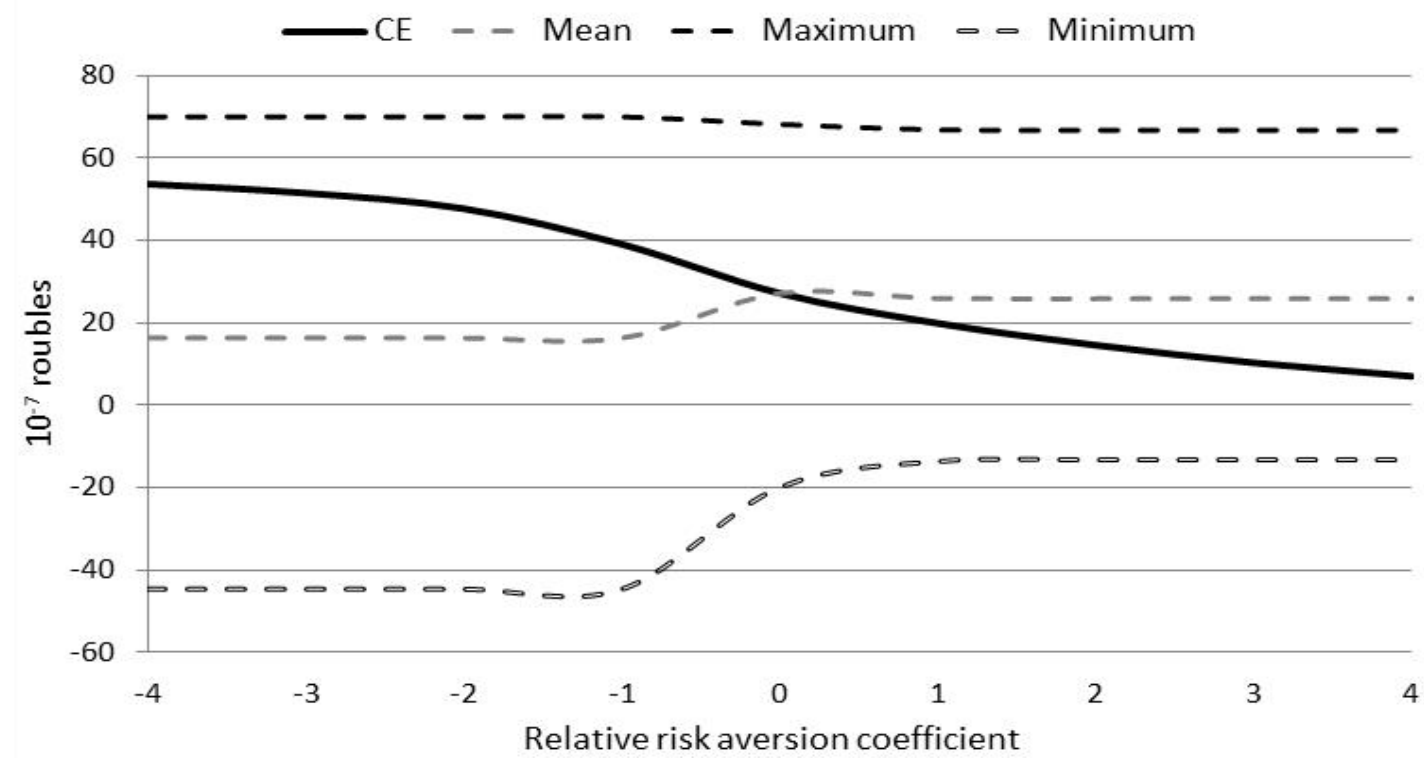

Figure 2 - Optimum net return (prospective basis) frontier with respect to the risk aversion 
RJOAS, 7(55), July 2016

Table 1 - Optimal crop portfolio set on the retrospective basis with respect to risk aversion

\begin{tabular}{|c|c|c|c|c|c|c|c|c|c|c|}
\hline \multirow{2}{*}{$\mathrm{Rr}$} & \multicolumn{6}{|c|}{ Acreage } & \multirow{2}{*}{ CE } & \multirow{2}{*}{ Mean } & \multirow{2}{*}{ Minimum } & \multirow{2}{*}{ Maximum } \\
\hline & Soybeans & Corn & Winter wheat & Sunflower & Spring wheat & Spring barley & & & & \\
\hline \multicolumn{11}{|c|}{ units } \\
\hline- & ha & ha & ha & ha & ha & ha & $10^{\prime}$ rubles & $10^{\prime}$ rubles & $10^{\prime}$ rubles & $10^{\prime}$ rubles \\
\hline-4.00 & 0 & 20,000 & 0 & 0 & 0 & 0 & 66.5 & 16.6 & -21.3 & 76.4 \\
\hline-3.00 & 0 & 20,000 & 0 & 0 & 0 & 0 & 63.2 & 16.6 & -21.3 & 76.4 \\
\hline-2.00 & 0 & 20,000 & 0 & 0 & 0 & 0 & 56.7 & 16.6 & -21.3 & 76.4 \\
\hline-1.00 & 0 & 20,000 & 0 & 0 & 0 & 0 & 41.3 & 16.6 & -21.3 & 76.4 \\
\hline-0.50 & 0 & 20,000 & 0 & 0 & 0 & 0 & 28.6 & 16.6 & -21.3 & 76.4 \\
\hline $0.00^{\mathrm{b}}$ & 0 & 17,140 & 0 & 2,860 & 0 & 0 & 17.2 & 17.2 & -16.4 & 69.0 \\
\hline 0.25 & 0 & 13,710 & 0 & 2,860 & 0 & 3,430 & 13.5 & 16.6 & -14.0 & 59.1 \\
\hline 0.50 & 0 & 9,340 & 0 & 2,860 & 0 & 7,800 & 11.1 & 15.7 & -12.9 & 46.5 \\
\hline 0.75 & 0 & 7,950 & 790 & 2,860 & 0 & 8,400 & 9.2 & 15.4 & -12.2 & 42.4 \\
\hline 1.0 & 1,880 & 5,890 & 2,620 & 2,860 & 0 & 6,750 & 7.6 & 14.9 & -10.5 & 39.4 \\
\hline 1.50 & 4,440 & 3,440 & 5,480 & 2,860 & 0 & 3,780 & 5.2 & 14.2 & -8.2 & 36.4 \\
\hline 2.00 & 5,280 & 2,250 & 8,410 & 2,860 & 0 & 1,200 & 3.6 & 13.9 & -6.6 & 34.1 \\
\hline 2.50 & 5,490 & 1,590 & 10,060 & 2,860 & 0 & 0 & 2.4 & 13.7 & -5.9 & 34.3 \\
\hline 3.00 & 5,600 & 1,000 & 10,540 & 2,860 & 0 & 0 & 1.6 & 13.5 & -5.5 & 34.5 \\
\hline 3.50 & 5,620 & 460 & 11,060 & 2,860 & 0 & 0 & 1.0 & 13.4 & -5.2 & 34.7 \\
\hline 4.00 & 5,590 & 0 & 11,550 & 2,860 & 0 & 0 & 0.5 & 13.3 & -4.9 & 35.0 \\
\hline
\end{tabular}

Table 2 - Optimal crop portfolio set on the prospective basis with respect to risk aversion

\begin{tabular}{|c|c|c|c|c|c|c|c|c|c|c|c|}
\hline \multirow[b]{2}{*}{$\mathrm{Rr}$} & \multicolumn{7}{|c|}{ Acreage } & \multirow{2}{*}{ CE } & \multirow[b]{2}{*}{ Mean } & & \multirow[b]{2}{*}{ Maximum } \\
\hline & Soybeans & Corn & Winter wheat & Sunflower & Spring wheat & Spring barley & & & & Minimum & \\
\hline \multicolumn{12}{|c|}{ units } \\
\hline - & ha & ha & ha & ha & ha & ha & & $10^{\prime}$ rubles & $10^{\prime}$ rubles & $10^{\prime}$ rubles & $10^{\prime}$ rubles \\
\hline-4.00 & 0 & 20,000 & 0 & 0 & & 0 & 0 & 53.7 & 16.3 & -44.7 & 70.0 \\
\hline-3.00 & 0 & 20,000 & 0 & 0 & & 0 & 0 & 51.5 & 16.3 & -44.7 & 70.0 \\
\hline-2.00 & 0 & 20,000 & 0 & 0 & & 0 & 0 & 47.7 & 16.3 & -44.7 & 70.0 \\
\hline-1.00 & 0 & 20,000 & 0 & 0 & & 0 & 0 & 39.1 & 16.3 & -44.7 & 70.0 \\
\hline-0.50 & 0 & 5,140 & 12,000 & 2,860 & & 0 & 0 & 30.9 & 27.2 & -19.9 & 68.2 \\
\hline $0.00^{c}$ & 0 & 5,140 & 12,000 & 2,860 & & 0 & 0 & 27.2 & 27.2 & -19.9 & 68.2 \\
\hline 0.50 & 0 & 5,140 & 12,000 & 2,860 & & 0 & 0 & 23.3 & 27.2 & -19.9 & 68.2 \\
\hline 0.75 & 2,510 & 2,630 & 12,000 & 2,860 & & 0 & 0 & 21.4 & 26.5 & -16.7 & 67.5 \\
\hline 1.00 & 4,850 & 290 & 12,000 & 2,860 & & 0 & 0 & 19.9 & 25.9 & -13.7 & 66.8 \\
\hline 2.00 & 5,140 & 0 & 12,000 & 2,860 & & 0 & 0 & 14.6 & 25.9 & -13.3 & 66.8 \\
\hline 3.00 & 5,140 & 0 & 12,000 & 2,860 & & 0 & 0 & 10.3 & 25.9 & -13.3 & 66.8 \\
\hline 4.00 & 5,140 & 0 & 12,000 & 2,860 & & 0 & 0 & 7.0 & 25.9 & -13.3 & 66.8 \\
\hline
\end{tabular}

${ }^{\mathrm{b}}$ To be able to run calculation, author used $10^{-6}$ instead of null.

${ }^{\mathrm{c}}$ To be able to run calculation, author used $10^{-6}$ instead of null. 


\section{CONCLUSIONS}

Crop return data cannot be the only factor exploited for decision making. New crop for CBSR of Russia such as corn provide higher returns in comparison to winter wheat, but bear risk as well. Corn as a monocrop can be optimal only for risk lovers. Slightly risk-averse farmers, which usually can be expected, would diversify production to diminish potential losses. Poor development of insurance service and governmental support force farmers in Russia to use crop portfolio diversification as a risk reducer. In the case of status quo, a future shift to a corn-soybeans rotation or corn as a monocrop, as seen in some parts of the United States (Taheripour et al., 2015), is unlikely.

Performed calculations are not without flaws: Some data come from different sources and Russian crop production varies considerably among farmers, so that a single farm's ability to reflect production patterns of even a single region is limited. However, despite the scarcity of data, the explored manner of risk handling clarifies uncertainty in a reliable way.

Better risk management will help businesses operate in a more efficient manner. As explained in this paper, analysis can be used not only to rank alternatives to be considered by a decision maker, but can be exploited as a tool for broader solutions when the decision maker finds it difficult or is unable to formulate all alternatives. Improved analysis affords handling uncertainty to find the best solution in given circumstances.

Both approaches used in the paper can be easily adopted and applicable for risk assessment and strategy development in the private sector as well as by policy makers in the public sector. The combination of linear programming and dynamic methods of calculation does not require advanced knowledge of dedicated software; all calculations here have been performed in Microsoft Excel.

\section{ACKNOWLEDGEMENTS}

This paper was prepared with the financial support of the agri benchmark Cash Crop Network (http://www.agribenchmark.org). The author grateful to Prof. Dr. Oliver Musshoff, Dr. Yelto Zimmer and Dr. Frank Offermann for very helpful comments and advice on an early draft of this paper and to Linda Smith for language corrections of the paper.

\section{REFERENCES}

1. agri benchmark (2014). Who we are. http://www.agribenchmark.org/agri\%20benchmark/ who-we-are.html Accessed 12 May 2014.

2. Anderson, J. R., Dillon, J. L. (1992). Risk analysis in dryland farming systems. Food \& Agriculture Org.

3. Arrow, K.J. (1965). Aspects of the Theory of Risk-Bearing. - Yrjö Jahnssonin Säätiö, Academic Bookstore, Helsinki.

4. Bell, D. E. (1988). One-switch utility functions and a measure of risk. Management science 34(12): 1416-1424.

5. Capolei, A., Foss, B., \& Jørgensen, J. B. (2015). Profit and Risk Measures in Oil Production Optimization. IFAC-PapersOnLine, 48(6), 214-220.

6. Chavas, J. P., Holt, M. T. (1990). Acreage Decisions under Risk - the Case of Corn and Soybeans. American Journal of Agricultural Economics 72(3): 529-538.

7. Chetvertakov, S. (2015) Corn and soy in Russia: the latest fad or a new cash cow? Proceedings of the 24th International Scientific Conference Agrarian Perspectives XXIV. - Global Agribusiness and Rural Economy: 199-207. DOI: 10.13140/RG.2.1.1054.7929

8. Doran, T. (2014) Corn, Soybean Export Locomotive Rolls On. AgriNews, 15 April 2014. http://agrinews-pubs.com/Content/News/Markets/Article/Corn--soybean-exportlocomotive-rolls-on-/8/26/10161 Accessed 10 May 2014.

9. GKS regional (2015). http://www.gks.ru/dbscripts/munst/munst20/DBInet.cgi Accessed 19 August 2015.

10. Gov (2015). Resolution of the Russian Government "About Establishment of the export customs duty rate on wheat." http://government.ru/docs/18291/ Accessed 23 June 2015. 
11. Hardaker, J. B., Richardson, J. W., Lien, G., and Schumann, K. D. (2004). Stochastic Efficiency Analysis with Risk Aversion Bounds: A Simplified Approach. Australian Journal of Agricultural and Resource Economics, 48(2): 253-270.

12. Hardaker, J. B., Huirne, R. B., Anderson, J. R., and Lien, G. (2004). Coping with Risk in Agriculture. CABI Publishing.

13. Hazell, P. B. (1971). A Linear Alternative to Quadratic and Semivariance Programming for Farm Planning Under Uncertainty. American Journal of Agricultural Economics 53(1): 53-62.

14. Hazell, P. B., Norton, R. D. (1986). Mathematical Programming for Economic Analysis in Agriculture. New York: Macmillan.

15. Ladanyi, M. (2008). Risk Methods and Their Applications in Agriculture. Applied Ecology and Environmental Research 6(1): 147-164.

16. Meyer, D. J., and Meyer, J. (2005). Relative Risk Aversion: What Do We Know? Journal of Risk and Uncertainty 31(3): 243-262.

17. Meyer, J. (1977). Choice Among Distributions. Journal of Economic Theory 14(2): 326336.

18. Mula, J., Poler, R., Garcia-Sabater, J., and Lario, F. C. (2006). Models for Production Planning Under Uncertainty: A Review. International Journal of Production Economics 103(1): 271-285.

19. Munro, E. (2013). Strong Corn Competition from Russia, Ukraine. Corn and Soybean Digest, 16 December 2013. http://cornandsoybeandigest.com/issues/strong-corncompetition-russia-ukraine Accessed 9 May 2014.

20. NAAI (2015). International Round Table of NAAl: Agricultural Insurance in Russia Prepares for a New Stage. National Association of Agriculture Insurers. http://www.naai.ru/eng/press-

tsentr/nsa_news/international_round_table_of_naai_agricultural_insurance_in_russia_pre pares_for_a_new_stage/ Accessed 23 June $20 \overline{0} 15$.

21. Nakamura, $\bar{Y}$. (1996). Sumex Utility Functions. Mathematical Social Sciences 31(1): 3947.

22. Osaki, M., and Batalha, M. O. (2014). Optimization Model of Agricultural Production System in Grain Farms Under Risk in Sorriso, Brazil. Agricultural Systems 127: 178-188.

23. Pratt, J.W. (1964). Risk Aversion in the Small and in the Large. Econometrica 32: 122136.

24. Richardson, J. W. and Outlaw, J. L. (2007). Training Commercial Farmers How to Analyse and Rank Risky Alternatives. In Proceedings of the 16th International Farm Management Association Congress.

25. Saha, A. (1993). Expo-power Utility: A 'Flexible' Form for Absolute and Relative Risk Aversion. American Journal of Agricultural Economics 75(4): 905-913.

26. Schumann, K. D., Richardson, J. W., Lien, G., Hardaker, J. B. (2004). Stochastic efficiency analysis using multiple utility functions. Paper presented at the AAEA Annual Meeting.

27. Taheripour, F., Fiegel, J., Tyner, W. E., (2015). Development of Corn Stover Biofuel: Impacts on Corn and Soybean Markets and Crop Rotation. Sustainable Agriculture Research, 5(1), 1.

28. UniSIS (2015). Unified Interdepartmental Statistical Information System of the Russian Federation. http://www.fedstat.ru/ Accessed 19 August 2015.

29. Vilhelm, V. (2011). The Role of Public Support of Risk Management in Agriculture. In Proceedings of the 20th International Scientific Conference Agrarian Perspectives, Prague, pp. 179-186. ISBN 978-80-213-2196-0

30. Vorotnikov, V. (2012). Russia is Producing more Soybeans and Corn. All About Feed, 2 March 2012; updated 6 August 2012. http://www.allaboutfeed.net/Nutrition/RawMaterials/2012/3/Russia-is-producing-more-soybeans-and-corn-AAF012875W/ Accessed 10 May 2014. 
APPENDIX 1 - CUMULATIVE DISTRIBUTION FUNCTION OF NET RETURN RELATIVE TO RISK AVERSE WITH RETROSPECTIVE CALCULATION

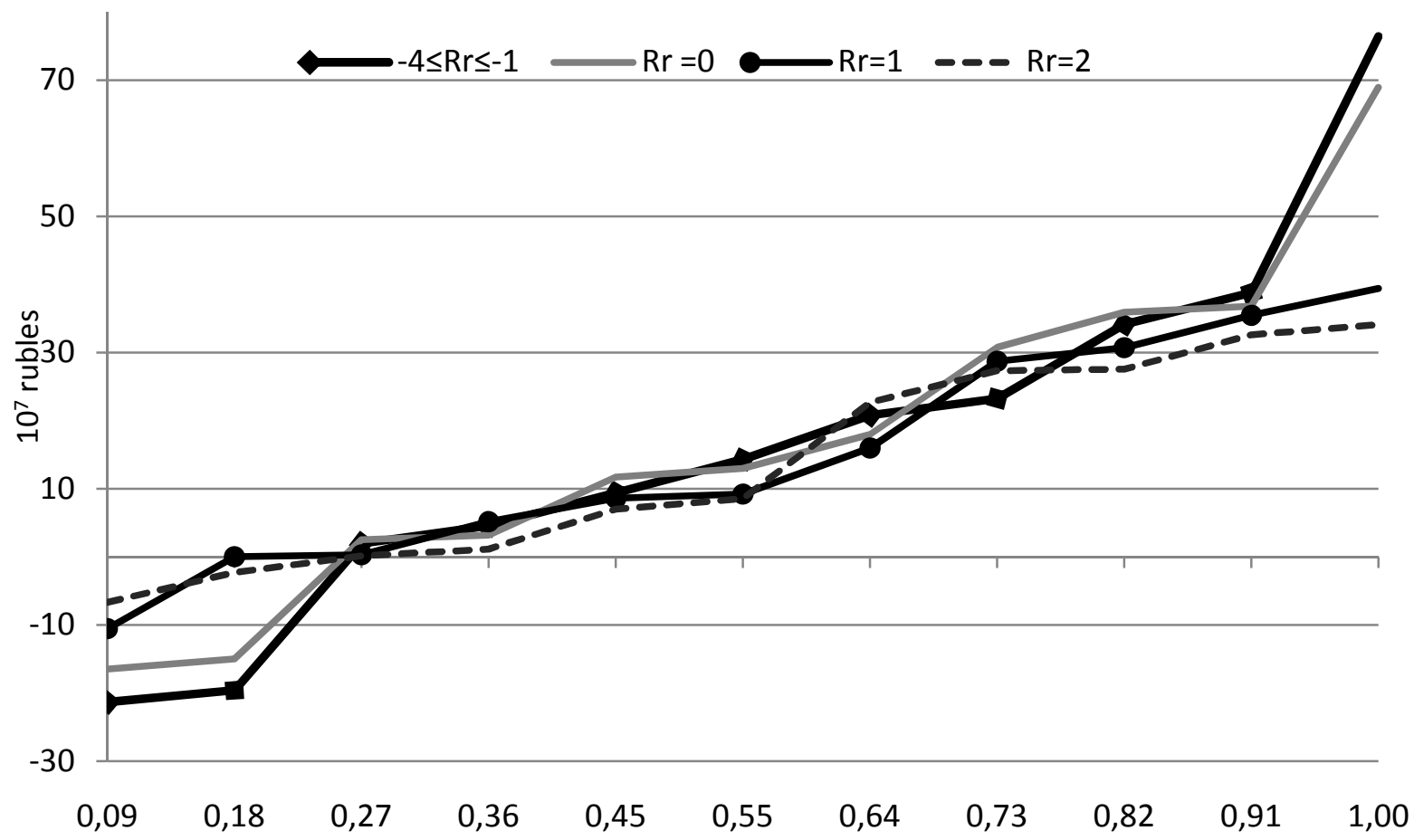

APPENDIX 2 - CUMULATIVE DISTRIBUTION FUNCTION OF NET RETURN RELATIVE TO RISK AVERSE WITH PROSPECTIVE CALCULATION

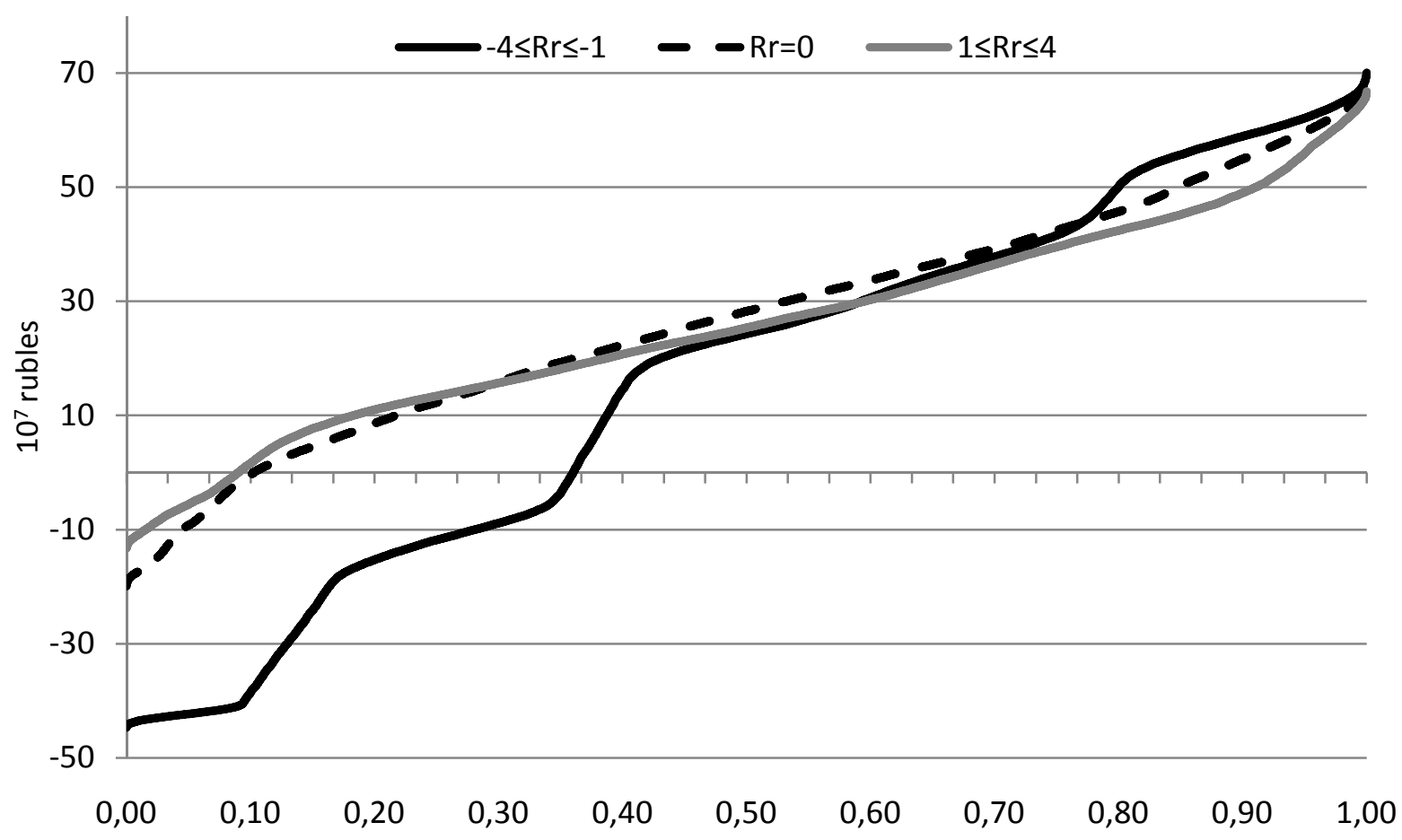




\title{
Welfare Analysis of Lifting the GM Ban in Russia
}

\author{
S. Chetvertakov \\ Institute of Farm Economics, Thunen-Institut, Germany
}

\begin{abstract}
Use of genetically modified crops is prohibited in Russia, however, Russian politicians are currently discussing this technology. This article evaluates the potential welfare effects of adopting genetically modified crops in Russia, focusing on the potential benefits to Russian producers who adopt herbicide tolerant corn and soybeans. Calculations are based on supply and demand functions of current market situations and their potential shifts. The results quantify the potential monetary gains from open markets to genetic engineering technology and explain the potential additional costs related to technology adoption.
\end{abstract}

\section{Keywords}

Welfare analysis, GM, corn, soybeans, Russia

Chetvertakov, S. (2016) "Welfare Analysis of Lifting the GM Ban in Russia", AGRIS on-line Papers in Economics and Informatics, Vol. 8, No. 2, pp. 49-56. ISSN 1804-1930. DOI: 10.7160/aol.2016.080204.

\section{Introduction}

The battle of sanctions that began in 2014 between the Russian Federation and its some trade partners resulted in constraints for the entire Russian economy, and it especially affected the agricultural sector. Maintenance of economy required from the government initiation of anti-crisis activity to stabilize the economy (Gov (b), 2015), but they were unsuccessful in controlling the weakening economy. The national currency fell and the Central Bank raised the interest rate. Higher interest rates and the growing inflation rate demanded changes to the current level of agricultural subsidies (Gov (a), 2015). In the face of government financial constraints, which are the results of sanctions on Russia, an important question can be raised: what alternative sources can be used to support agricultural producers?

Widespread innovations such as genetically modified seeds cannot be applied legally in Russia, despite demand for this technology from the production sector. In 2012, a law that would open the gate for genetically modified (GM) crops was proposed (MEDRF, 2012), but did not pass. Political discussion regarding adoption of GM seeds inclines to the position of GM opponents and Russian policy-makers, employing the argument of unpredictable outcomes for human health and the environment, kept GM seeds out of Russia (Lenta, 2015; Kommersant, 2015). In Russia and other countries that prohibit the production of GM crops, there is particular interest in economic compensation for the welfare losses resulting from these market constraints (Moschini et. al., 2000).

The possible effects of GM crop adoption have been calculated for many regions and different crops (Trigo and Cap, 2004; Raney, 2006). Brookes and Barfoot (2014) argue that the main reason for the current adoption of GM herbicide tolerant (HT) crops has been lower production costs. Although there is some evidence of a yield advantage (Brookes and Barfoot, 2014), this effect cannot be generalized (Finger et al., 2011).

Potential welfare effects of GM seed adoption in the Russian economy have not been studied. This paper estimates the welfare changes of Russian producers in the case of access to GM seeds. The specific focus of the study is HT corn and soybeans.

Particular interest in substituting GM corn and soybeans for conventional varieties stems from the fast acreage expansion of these crops and their growing importance in Russian agriculture. The average annual growth rate (2000-2013) for both crops was $10.2 \%^{1}$ across Russia. In this same period, average annual growth rates reached $17.3 \%$ and $32.8 \%$ for corn and soybeans, respectively, in the Central Federal District, one of country's main agricultural regions.

Insect resistant corn was also considered

${ }^{1}$ Own calculation based on official statistics from UniSis database, 2015. 
for the study, but there is a relative lack of necessary data. First of all, the effects of insect resistant corn use depend significantly on pest infestation levels (Baute et. al., 2002). Some regional studies (Potemkina and Lastushkina, 2006; Serapionov and Frolov, 2008) do not track pest infestation levels in corn growing regions. Secondly, few studies include economic performance figures of farms using Bt corn (Finger et al., 2011), making economic analysis difficult. Finally, there is also considerable ambiguity about the yield effects of using Bt corn (Finger et al., 2011). All of these make estimating the welfare effects of Bt corn in Russia difficult.

This paper is organized as follows: the second section describes and discusses methods which will be used in the paper; the third section provides the results. The discussion regarding the pitfalls of the GM legislation and conclusion will finalize the paper.

\section{Materials and methods}

Russian corn and soybean market models are assumed to take the following functional forms, following the linear supply and demand equations:

$$
\begin{aligned}
& \mathrm{D}(\mathrm{Q})=\mathrm{P}=\mathrm{a}_{0}+\mathrm{a}_{1} \mathrm{Q}^{\mathrm{d}} \\
& \mathrm{S}(\mathrm{Q})=\mathrm{P}=\mathrm{b}_{0}+\mathrm{b}_{1} \mathrm{Q}^{\mathrm{s}}
\end{aligned}
$$

The starting point of model construction is estimating the current situation. Calculation of the demand and supply equations requires initial data that was taken from three sources: production and trade data (total production, consumption, exports, imports, etc.) for 2013/2014 growing season $^{2}$ come from the USDA database (2015); Russian corn and soy supply and demand elasticities come from the FAPRI Elasticity Database (2015); the average prices in Russia for the selected season were gathered (and then converted to US dollars) from UniSis database (2015).

\section{Corn}

Corn balance in 2013/2014 was as follows: total supply ${ }^{3}$ was $\mathrm{Q}_{0}^{\mathrm{s}}=11,642 \mathrm{mln}$. metric tons (MT), total demand (consumption) $\mathrm{Q}_{\mathrm{dc}}=7,500 \mathrm{mln}$. MT and net export 4,142 mln. MT. Supply elasticity (area) is equal to $\mathrm{e}_{\mathrm{s}}=0.31$. Average price for the season was $\mathrm{P}=\$ 173.56$ per MT. There

\footnotetext{
${ }^{2}$ The local marketing year for Russia for corn and soybeans is October 2013 to September 2014

3 Calculated as the sum of beginning stocks and production less ending stocks.
}

are two demand elasticities based on the two uses of corn for animal feed and human consumption. As the majority of the total consumption (88\%) is used for animal feeding, the author employs the elasticity relative to this use, which is equal to $e_{d}=-0.2$. It is also possible to calculate one demand elasticity based on the two uses or apply other solutions, but as will be explained later, demand elasticity does not influence the consumer welfare alteration.

Given the above values, it is possible to derive the four unknowns in the supply and demand equations:

$\mathrm{a}_{1}=\left(\frac{1}{\mathrm{e}_{\mathrm{d}}}\right) \times\left(\frac{\mathrm{P}}{\mathrm{Q}_{\mathrm{dc}}}\right)$

$\mathrm{a}_{0}=\mathrm{P}-\mathrm{a}_{1} \mathrm{Q}^{\mathrm{d}}$

Substituting $\mathrm{b}_{0}$ and $\mathrm{b}_{1}$ for $\mathrm{a}_{0}$ and $\mathrm{a}_{1}$, respectively, the necessary parameters for the supply function are also calculated. The demand and supply curves are drawn in Figure 1. Further calculations reveal the $\mathrm{x}$-intercept of the supply function $\mathrm{S}_{0}$ and horizontal axis, which is $\mathrm{Q}_{0}$ equal to $8,033 \mathrm{mln}$. MT. Lifting the GM ban will lead to cost savings, which will shift the supply curve $\mathrm{S}_{0}$ downward to $\mathrm{S}_{1}$.

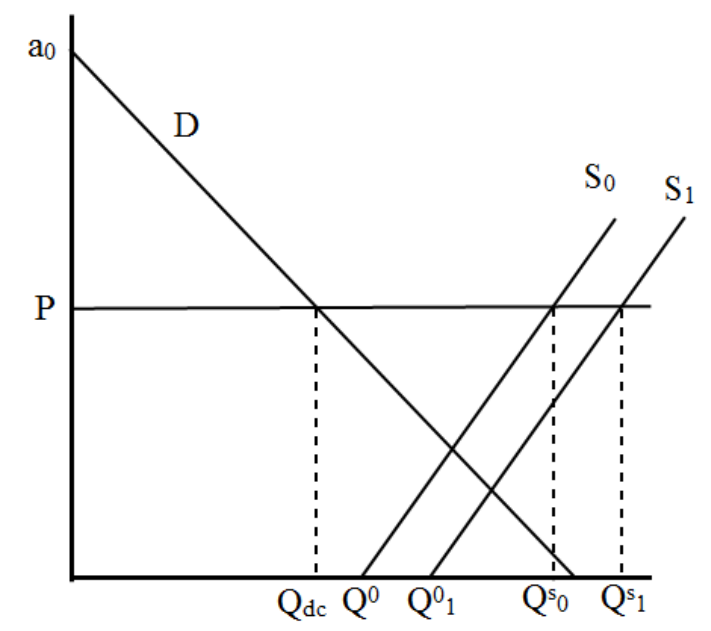

Source: own processing

Figure 1. Corn market in 2013/2014

In this paper the author applies a small-country assumption: such that Russian production and trade policies does not affect the world market price. Therefore, the world demand for Russian corn is perfectly elastic and as long as domestic market is a world price taker, domestic consumer's welfare does not change due to the supply shift. However, there is another way of modelling the market. Moschini et al. (2000) employed 
a partial equilibrium model by measuring demand elasticities of importing countries. This method was not used because of two limitations:

1. The lack of quantity and destination data of corn exports (the UN Comtrade Database (2015) was considered as the source of such information, but was rejected due to limitations explained on their webpage).

2. Russia exports a negligible amount of corn relative to the world market and thus a slight increment of export quantities does not influence the world market.

One of the key challenges is quantifying the cost savings from the adoption of GM crops. Climate conditions do not influence on the economic performance of GM crops in comparison to conventional (Finger et al., 2011), which seems logic as trading by GM seeds and treatment materials companies adjust prices to the potential farmer's return. Hence, climate conditions are not considered to have an effect on crop production costs, and therefore, cost-savings resulting from use of GM or conventional seeds.

The paper from Brookes and Barfoot (2014) presents a summary of economic impacts of GM crops over many countries. Income benefits resulting from both lower input costs (cost savings) as well as yield gains will be considered in this study. Although Finger et al. (2011) argue that yield increase of GM crops cannot be generalized, this factor cannot be ignored. Therefore, yield gains are included in the calculation of the monetary benefits of GM use, but conventional and GM crop yields were assumed to be the same for the calculation. Different benefit level will reflect the sensitivity of the welfare in depends to the average farm benefit, which differs from year to year due to fluctuation in price of herbicide, seed cost, cost of technology and yield. The lowest (\$1 per hectare in South Africa) and the highest (\$90 per hectare in Argentina) values of the farm income benefit (after deduction of cost of technology) will be the limits.

Welfare effects of open access to GM seeds in Russia compared to the current situation can be measured as geometric areas. Current consumer surplus CSA is the area below the demand curve D and above the price $\mathrm{P}$ :

$\mathrm{CS}^{\mathrm{A}}=\frac{1}{2}\left(\mathrm{a}_{0}-\mathrm{P}\right) \times \mathrm{Q}_{\mathrm{dc}}$

Current producer surplus PS $^{\mathrm{A}}$ can be measured as the area above the current supply curve $S_{0}$ and below the price $\mathrm{P}$ :

$$
\begin{aligned}
\mathrm{PS}^{\mathrm{A}}=\left(\mathrm{Q}^{0} \times \mathrm{P}\right) & +\frac{1}{2}\left(\left(\mathrm{Q}_{0}^{\mathrm{S}}-\mathrm{Q}^{0}\right) \times \mathrm{P}\right) \\
& =0.5 \mathrm{P}\left(\mathrm{Q}_{0}^{\mathrm{S}}+\mathrm{Q}^{0}\right)
\end{aligned}
$$

After potential change in the Russian legislation the supply curve will move downward, increasing producer surplus. This amount will be calculated as income benefit per ha divided by the actual yield (5.01 MT per ha). This figure will reflect the income benefit per metric ton basis. The new supply curve function will be:

$\mathrm{S}_{1}(\mathrm{Q})=\mathrm{P}=\mathrm{b}_{0}-\mathrm{c}+\mathrm{b}_{1} \mathrm{Q}_{1}^{\mathrm{s}}$

where $\mathrm{c}$ is the amount of income benefits in US dollars per metric ton and $\mathrm{Q}^{\mathrm{S}}$ is a new supplied amount.

New producer surplus PS $^{\mathrm{N}}$ can be calculated as:

$$
\begin{aligned}
\mathrm{PS}^{\mathrm{N}}=\left(\mathrm{Q}_{1}^{0} \times \mathrm{P}\right) & \left.+\frac{1}{2}\left(\mathrm{Q}_{1}^{\mathrm{S}}-\mathrm{Q}_{1}^{0}\right) \times \mathrm{P}\right) \\
& =0.5 \mathrm{P}\left(\mathrm{Q}_{1}^{\mathrm{S}}+\mathrm{Q}_{1}^{0}\right)
\end{aligned}
$$

\section{Soybeans}

Unlike corn, soy is a scarce commodity in Russia and the domestic production provides only half of the total domestic consumption. Total domestic supply ${ }^{4}$ of soybeans in 2013/2014 was $\mathrm{Q}^{\text {sd }}{ }_{0}=1,453 \mathrm{mln}$. MT, net import $1,907 \mathrm{mln}$. MT and the total domestic consumption $\mathrm{Q}_{\mathrm{dc}}=3,360 \mathrm{mln}$. MT. Supply elasticity (area) is not specified for Russia in the FAPRI database, so the elasticity for CIS $^{5}$ countries is used, which is $\mathrm{e}_{\mathrm{s}}=0.42$. Average price for the marketing season is $\mathrm{P}=\$ 504.97$ per MT. Demand represents two components: feed demand and demand for crushing, and there is absence of consolidated demand elasticity for beans. Author uses Moschini et al. (2000) calculations of bean elasticity for the rest of the world, which is $e_{d}=-0.4$. However, as in the case of corn, the small country assumption will be applied and consumer welfare will not change due to the supply move.

Exploiting equations (3) and (4), it is possible to calculate the supply and demand functions (figure 2). Further calculations are used to derive the crossing point of supply function $\mathrm{S}_{0}$ and horizontal axis, which is $\mathrm{Q}_{0}=842.7 \mathrm{mln}$. MT.

Net gains from planting GM herbicide tolerant soybeans are difficult to estimate as the effect of the following crop may also have an impact. A paper by Brookes and Barfoot (2014) simulate a range of possible net farm benefits from GM

\footnotetext{
${ }^{4}$ treated the same manner as corn supply

5 The Commonwealth of Independent States
} 
technology in several countries and different GM technologies. The minimum farm income benefit was observed in South Africa and equal to \$4 per hectare ( $1^{\text {st }}$ generation GM HT soybeans) and the highest was $\$ 149$ in the US ( $2^{\text {nd }}$ generation GM HT soybeans). This range of benefits will be used to calculate the potential welfare gain.

Equations 5-8 presented in the corn part can be employed to measure soybean welfare as well. Amount of the benefits per ton is calculated by dividing net gains from GM per hectare by the yield level of the selected season, which was $1.36 \mathrm{MT} / \mathrm{ha}$.

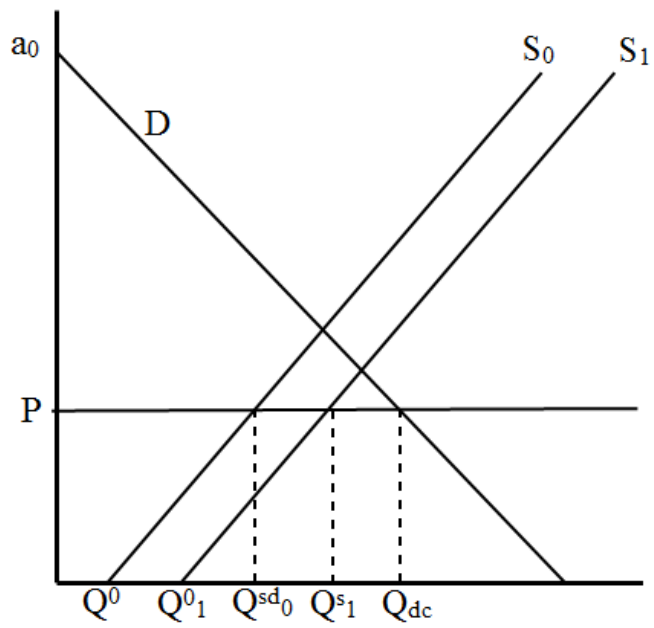

Source: own processing

Figure 2. Soybean market in 2013/2014.

\section{Results and discussion}

\section{Corn}

First, consumer and producer surplus are calculated for the current situation of no access to GM seeds.
Corn consumers have surplus equal to $\$ 3,254 \mathrm{mln}$., and corn producer surplus is $\$ 1,707 \mathrm{mln}$. Sequentially, by substituting income benefits into equation (7), and then subtracting current producer surplus from potential producer surplus, change in the producer welfare, $\triangle \mathrm{PS}$, is found. The results for selected amounts of income benefits per hectare relative to the potential adoption rate of GM corn in Russia are presented in Table 1. Adoption rate was applied to indicate the different welfare outcomes. Lifting the GM ban would not lead immediately to wide acceptance by farmers. The number of producers who will use GM seeds will affect the total producer surplus area.

Increase of producer surplus is a result of growth in supply. For example, with $\$ 30$ per ha of income benefit and 100\% technology adoption, producer supply will increase by 124.5 thousand MT (going to export) which leads to additional $\$ 21.6 \mathrm{mln}$. in producer surplus at a price of $\$ 173.56$ per MT.

\section{Soybeans}

Russian soybean consumers benefit from the world market price as it is located below the domestic market price. Their current consumer surplus is equal to $\$ 4,242 \mathrm{mln}$., while producer surplus is only $\$ 580 \mathrm{mln}$. Possible welfare gains from access to GM HT soybeans are reflected in Table 2. Income benefits will slightly affect the quantity of soybeans produced domestically. With $\$ 50$ per ha benefit from GM technology, soybean growers would be ready to increase soybean planting by 32,670 hectares, which leads to additional production of about 44.4 thousand MT (with yield $1.36 \mathrm{MT} / \mathrm{ha}$ ). In such case Russian soybean producers would reap an additional $\$ 22 \mathrm{mln}$.

\begin{tabular}{|c|c|c|c|c|}
\hline \multirow{2}{*}{$\begin{array}{c}\text { Income benefit } \\
\text { per hectare }\end{array}$} & \multicolumn{4}{|c|}{ Adoption rate } \\
\cline { 2 - 5 } & $25 \%$ & $50 \%$ & $75 \%$ & $100 \%$ \\
\hline$\$ 1$ & 0.18 & 0.36 & 0.54 & 0.72 \\
\hline$\$ 10$ & 1.8 & 3.6 & 5.4 & 7.2 \\
\hline$\$ 20$ & 3.6 & 7.2 & 10.8 & 14.4 \\
\hline$\$ 30$ & 5.4 & 10.8 & 16.2 & 21.6 \\
\hline$\$ 40$ & 7.2 & 14.4 & 21.6 & 28.8 \\
\hline$\$ 50$ & 9.0 & 18.0 & 27.0 & 36.0 \\
\hline$\$ 60$ & 10.8 & 21.6 & 32.4 & 43.2 \\
\hline$\$ 70$ & 12.6 & 25.2 & 37.8 & 50.4 \\
\hline$\$ 80$ & 14.4 & 28.8 & 43.2 & 57.6 \\
\hline$\$ 90$ & 16.2 & 32.4 & 48.6 & 64.8 \\
\hline
\end{tabular}

Source: own processing

Table 1. Estimated impact on producer's welfare with GM HT corn application in Russia (Millions of USD). 


\begin{tabular}{|c|c|c|c|c|}
\hline \multirow{2}{*}{$\begin{array}{c}\text { Income benefit } \\
\text { per hectare }\end{array}$} & \multicolumn{4}{|c|}{ Adoption rate } \\
\cline { 2 - 5 } & $25 \%$ & $50 \%$ & $75 \%$ & $100 \%$ \\
\hline$\$ 4$ & 0.45 & 0.90 & 1.35 & 1.79 \\
\hline$\$ 20$ & 2.24 & 4.49 & 6.73 & 8.97 \\
\hline$\$ 35$ & 3.93 & 7.85 & 11.78 & 15.71 \\
\hline$\$ 50$ & 5.61 & 11.22 & 16.83 & 22.44 \\
\hline$\$ 65$ & 7.29 & 14.58 & 21.88 & 29.17 \\
\hline$\$ 80$ & 8.97 & 17.95 & 26.92 & 35.90 \\
\hline$\$ 95$ & 10.66 & 21.31 & 31.97 & 42.63 \\
\hline$\$ 110$ & 12.34 & 24.68 & 37.02 & 49.36 \\
\hline$\$ 125$ & 14.02 & 28.04 & 42.07 & 56.09 \\
\hline$\$ 140$ & 15.71 & 31.41 & 47.12 & 62.82 \\
\hline$\$ 149$ & 16.71 & 33.43 & 50.14 & 66.86 \\
\hline
\end{tabular}

Source: own processing

Table 2. Estimated impact on producer's welfare with GM HT soybeans application in Russia (Millions of USD).

\section{Discussion}

Creation of a law to allow GM seeds and products to enter the market is not the only issue. Policymakers should also think about the procedure of admittance such products to allow producers to reap aforementioned benefits and guarantee food safety for consumers.

Around the world, current legislative practices with regard to GM products can be differentiated between two, rather extreme principles: substantial equivalence principle that treats GM as conventional food technology (OECD, 1992), as is applied in the U.S.; and precautionary principle that says in the case of a lack of scientific evidence it is better to ban a product that could be safe than accept one that could be dangerous (McGarity, 2001), as is applied in Europe. Most countries' legislation with respect to GM food falls between these two extremes (Chen, 2006). The precautionary principle hinders European growers to use GM technology, but this could change in the near future with extend of GM use in the Regulation on Genetically Modified food and feed (EC, 2015).

The author believes that politicians should construct rules with respect to GM technologies in a way to provide the necessary information to consumers and at the same time does not unequally disadvantage producers who wish to use GM or conventional products. The public is very sensitive to such issues and would rather avoid GM products. In this case labeling will play the major role.

With regards to labeling, studies reveal that when GM labeling is voluntary or mandatory, the outcome is equal (Bansal and Gruère, 2010). In the case of the type of labeling, rules should transparently define which products can be assigned as GM. Three categories of such products have to be determined:

1. GM food for direct consumption;

2. Food for animal feed that is later converted to other type of products;

3. GM food that is processed and can be sold for direct consumption or for use in production of other products.

Common practices of labeling the aforementioned categories are: GM food for direct consumption is labeled as being a GM food. Japan offers a good example of labeling the second and third categories: "Exempted processed foods are products such as those in which recombinant DNA or proteins produced by such DNA are finally eliminated or broken down..." (FAQ, 2003). In other words, if DNA of genetically modified product is broken such product should not be labeled as GM. With regards to the third category, Chinese law requires labeling products as GM if the share of GM ingredients is more than 5\% (Chen, 2006).

Definition of GM foods can be adjusted with legislation. But should non-GM food be labelled as well? This question is more difficult. In the case of Switzerland, 'GMO-free' labeling is prohibited because it is difficult to guarantee $0 \%$ GMO in the food (Regulation, 1997). This point is valid given the difficulty of separating GM and non-GM products during planting, transportation, and processing.

The aforementioned legislative practices can be adapted to the Russian case as well. Proper labeling of GM products will provide sufficient information to consumers, while not harming producers of GM products. 
Government policy in regards to handling and storage of GM products will impact the welfare effect from the technology. Additional costs will rise with the necessity to document, verify and separate transport and storage facilities for GM and non-GM products. However, the size of such additional costs depends on the crop, volume and the threshold level of contamination accepted (Stone et al., 2002).

Many authors have estimated such costs. For example, Buckwell et al. (1999) find that for the US market with tolerance level of GM residues of $1 \%$, additional costs were approximately $10 \%$ of farm gate prices. With this same tolerance level in Russia, it would require almost $\$ 87$ per ha of corn and $\$ 68.7$ per ha of soybeans. Interpreting these results, costs for GM corn handling are higher than most values of income benefits per ha seen in Table 1, which means that considering the handling and storage costs of GM HT corn can result in welfare losses. For soybeans additional costs are in the middle range of income benefits from the GM technology (Table 2), and so large welfare gains can occur. Aforementioned costs are calculated for the first period of GM introduction. Over time costs are expected to fall as procedures improve (Buckwell et al., 1999).

Another source (Leading Dog Consulting, 2001) presents an estimation from Australia, where additional costs for testing technology, segregation and identification systems will increase by $10-15 \%$ through the supply chain. Vandenberg et al. (2000) used a linear programming approach to evaluate different scenarios of segregation for existing GM corn and soybeans on the market and found that the total costs of the supply chain will increase in the range by $3-9 \%$. The European Commission (2000) estimated the costs will increase by $6-17 \%$ of the farm gate price.

Estimations of additional costs related to GM crop treatment vary and depend on the particular country case and chosen policy applied to the GM products. These estimations demand careful calculation as the additional costs in the supply chain can potentially cancel out the producers' welfare increase from the cost-saving technology.

The state can support farmers not only by subsidies, but opportunity to produce cheaper and, therefore, larger quantity of products and reap higher profits with GM introduction. Unlike subsidies, which are a redirection of financial resources from other sectors, producers will gain from free access to GM products without large state expenses. Additional welfare gains will accelerate soy and corn production.

\section{Conclusion}

The paper presents the possible gains to Russian producers from opening the market to GM seeds, in particular HT corn and soybean seeds. The term "producer" in this context does not refer to only farmers. Farmers share total producer welfare with other players in the inputs market. Lifting the GM ban will lead to a multiplier effect that touches all related industries.

Allowing GM technologies will not only affect producers who choose to plant GM seeds, but conventional growers as well. Seed companies will have to decrease the price of conventional seeds to compete with the new product. The same direction of price policy will adhere to retail companies who sell herbicide products for treatment of conventional varieties.

This paper examined the direct monetary effects only. However, GM crops lead to other benefits as well: the reduced tillage with HT crops leads to less machinery costs and release of machines for other operations; reduction in the amount of crop protection (or change to a less dangerous class of chemicals), which leads to environmental and health benefits. In addition, an increase of soybean production will lead to higher selfsufficient levels for this crop, which is a very important issue for Russian politicians.

Lifting the GM ban in Russia may lead to a considerable increase in the welfare of producers. Only taking into account these two GM crops: corn and soy (assuming a 50\% adoption rate and income benefits of $\$ 30$ and $\$ 50$ for corn and soy, respectively) results in income benefits equal to the current government subsidies for purchasing elite seeds (MCX, 2015).

The author does not intend to declare unambiguously that lifting the ban on GM products only yields benefits. Introduction of GM products will require developing and applying an identification and labeling system for GM and non-GM products, which can outweigh potential benefits. Environmental and health issues, as well as possible changes in the influence and market shares of multinational seed companies, should also be considered carefully. A comprehensive analysis of all pros and cons should be done as soon as possible so that Russia does not lose out on the potential welfare gains that are partly discussed in this paper. 


\section{Acknowledgements}

The author is grateful to Prof. Dr. Klaus Salhofer for very helpful comments and advice on an early draft of this paper and to Elizabeth Lunik for advice and language corrections of the paper.

\author{
Corresponding author: \\ Sergey Chetvertakov \\ Institut für Betriebswirtschaft, Bundesallee 50,38116 Braunschweig, Germany \\ E-mail: chetvertakovsergey@gmail.com
}

\title{
References
}

[1] Bansal, S., Gruère, G. (2010) "Labeling genetically modified food in India: economic consequences in four marketing channels" (No. 946), International Food Policy Research Institute (IFPRI).

[2] Baute, T. S., Sears, M. K., and Schaafsma, A. W. (2002). "Use of transgenic Bacillus thuringiensis Berliner corn hybrids to determine the direct economic impact of the European corn borer (Lepidoptera: Crambidae) on field corn in Eastern Canada." Journal of economic entomology. Vol. 95, No. 1, pp. 57-64. ISSN 0022-0493.

[3] Brookes, G., Barfoot, P. (2014) "Economic impact of GM crops", GM Crops \& Food, Vol. 5, No. 1, pp. 65-75. ISSN 2164-5698, E-ISSN 2164-5701, DOI: 10.4161/gmcr.28098.

[4] Buckwell, A., Brooks, G. Bradley, D., Barfoot, P., Tangermann, S. and Blom, J. (1999) " Economics of Identify Preservation for Genetically Modified Crops", Final Report of a study for Food Biotechnology Communications Initiative, Wye College, England.

[5] Chen, Christopher C. (2006) "Labeling Genetically Modified Food - Comparative Law Studies from Consumer's Perspective", National Taiwan University Law Review, Vol. 1, No. 1. [Online]. Available: http://ssrn.com/abstract=1832138 [Accessed 30 March 2015].

[6] EC (2015) Speaking points on Regulation on Genetically Modified food and feed - Council of the EU - Agriculture and Fisheries, European commission, 13 July 2015. [Online]. Available: https://ec.europa.eu/commission/2014-2019/andriukaitis/announcements/speaking-pointsregulation-genetically-modified-food-and-feed-council-eu-agriculture-and-fisheries_en [Accessed 20 July 2015].

[7] European Commission (2000) Economic Impacts of Genetically Modified Crops on the Agri-Food Sector, Directorate-General for Agriculture, March 2000.

[8] FAPRI (2015) Elasticity Database, Food and Agricultural Policy Research Institute. [Online]. Available: http://www.fapri.iastate.edu/tools/elasticity.aspx [Accessed 18 March 2015].

[9] FAQ (2003) "FAQs on Labeling System for Genetically Modified Foods" [Online]. Available: http:// www. mhlw.go.jp/english/topics/qa/gm-food/gm1.html [Accessed 02 January 2003].

[10] Finger, R., El Benni, N., Kaphengst, T., Evans, C., Herbert, S., Lehmann, B., Morse, S., Stupak, N. A . (2011) "Meta Analysis on Farm-Level Costs and Benefits of GM Crops", Sustainability, Vol. 3, No. 5, pp. 743-762. ISSN 2071-1050, DOI: 10.3390/Su3050743.

[11] Gov (2015a) The distribution of subsidies in 2015 to support agriculture, The Russian Government, [Online]. Available: http://government.ru/docs/16916/ [Accessed 18 March 2015].

[12] Gov (2015b), The plan of priority measures to ensure the sustainable economic development and social stability in 2015, The Russian Government. [Online]. Available: http://government.ru/ docs/16639/ [Accessed 18 March 2015].

[13] Kommersant (2015) The Russian government approved a ban on GMOs, ИД «Коммерсантъ», [Online]. Available: http://www.kommersant.ru/doc/2658384 [Accessed 15 March 2015].

[14] Leading Dog Consulting and Peter Flottmann and Associates (2001), Segregating Gene Technology Products - Requirements, Costs and Benefits of Identity Preservation, Segregation and Certification, Prepared for Commonwealth Department of Agriculture, Fisheries and Forestry, May. 
[15] Lenta (2015) The bill of a ban on cultivation of GMO in Russia is introduced in the State Duma, «Лента.Ру» интернет-газета, [Online]. Available: http://lenta.ru/news/2015/02/03/gmo/ [Accessed 15 March 2015].

[16] McGarity, T. O. (2001) Seeds of Distrust: Federal Regulation of Genetically Modified Foods, U. mich. JL reform, 35 Univ.of Mich. J. L. Reform 403.

[17] MCX (2015) Distribution of subsidies in the directions of the state support, Ministry of Agriculture of the Russian Federation. [Online]. Available: http://www.mcx.ru/documents/document/v7 show/31252..htm [Accessed 26 April 2015].

[18] MEDRF (2012) The draft of the resolution of the Russian Federation government "About the statement of the Order of the state registration of the gene engineering modified organisms intended for release in environment, and also the production received with application of such organisms or containing such organisms", Ministry of Economic Development of the Russian Federation. [Online]. Available: http://economy.gov.ru/minec/about/structure/ depregulatinginfluence/doc20121229_07 [Accessed 20 February 2015].

[19] Moschini, G., Lapan, H., Sobolevsky, A. (2000) "Roundup Ready® soybeans and welfare effects in the soybean complex", Agribusiness, Vol. 16, No. 1, pp. 33-55. E- ISSN: 1520-6297. DOI: 10.1002/(SICI)1520-6297(200024)16:1<33::AID-AGR4>3.0.CO;2-5

[20] OECD (1992) Safety Evaluation of Foods Derived by Modern Technology: Concept and Principle 1992.

[21] Potemkina, V. I., Lastushkina, E. N. (2006) "Asiatic corn borer (ostrinia furnacalis gn.) (lepidoptera, pyralidae) and the role of biotic factors on its decline in primorye region", A.I. Kurentsov's Annual Memorial Meetings, Vol. 17, pp. 107-113.

[22] Raney, T. (2006) "Economic impact of transgenic crops in developing countries". Current Opinion in Biotechnology. Vol. 17, No. 2, pp. 174-178. ISSN 1369-5274, DOI 10.1016/j.copbio.2006.02.009.

[23] Regulation (1997) Regulation (EC) No 258/97 of the European Parliament and of the Council of 27 January 1997 concerning novel foods and novel food ingredients, European Union law, No. 258/97, O.J. (L 043) 1.

[24] Serapionov, D.A., Frolov A.N. (2008) "Maize infestation by the $1^{\text {st }}$ generation European corn borer larvae and precipitation in May at the Krasnodar area: GIS mapping and georeferencing", Plant Protection News. Vol. 2, pp. 34-37. ISSN 1815-3682.

[25] Stone, S., Matysek, A. and Dolling, A. (2002) "Modelling Possible Impacts of GM Crops on Australian Trade", Productivity Commission Staff Research Paper, Melbourne, October.

[26] Trigo, E. J., Cap, E. J. (2004) "The impact of the introduction of transgenic crops in Argentinean agriculture", AgBioForum, Vol. 6, No. 3, pp. 87-94. [Online]. Available: http://www.agbioforum. org [Accessed 7 April 2015].

[27] UN Comtrade Database (2015) United Nations, [Online]. Available: http://comtrade.un.org/ [Accessed 3 March 2015].

[28] UniSis database (2015) Unified Interdepartmental Statistical Information System. [Online]. Available: http://www.fedstat.ru/indicators/start.do [Accessed 20 March 2015].

[29] USDA database (2015) Production, Supply and Distribution, United States Department of Agriculture Foreign Agricultural Service. [Online]. Available: http://apps.fas.usda.gov/psdonline/ psdQuery.aspx [Accessed 17 March 2015].

[30] Vandenberg, J. M., Fulton, J. R., Dooley, F. J., and Preckel, P. V. (2000) "Impact of identity preservation of non-GMO crops on the grain market system". CAFRI: Current Agriculture, Food and Resource Issues. Vol 01. 


\section{Summary of Findings and Conclusions}

The articles of this dissertation investigate the prospects of cash crop production in the CBSR of Russia. Chapters 2 and 3 analyse the existing trends of cash crop production in the CBSR; they provide an estimation of the possible drivers and further opportunities for corn and soybeans acreage extension. Chapter 4 extends the analysis of previous research by introducing a factor of uncertainty into the calculation. Chapter 5 discusses another opportunity for the development of cash crop production by assuming the introduction of GM technology in Russia, which is currently forbidden. Finally, Chapter 6 connects the previous chapters and summarizes the main results of each of the four preceding chapters.

\subsection{Corn and soy in Russia: The latest fad or a new cash cow?}

The first article describes and proves that the CBSR is indeed a new hotspot for corn and soybeans production. The chosen research method is afforded to receive the information on all relevant inputs and outputs in terms of quantities and prices.

To obtain the required information, 15 interviews were conducted. However, not all respondents were able to provide all necessary data, since the questions comprised sensitive information regarding the economic performance. Thus, only the performance of those farms that had sufficient data to calculate the results has been presented.

The overall composition of the respondents can be described as follows: one private farm, 12 independent enterprises or members of agricultural holdings, and two headquarters of agricultural holdings that manage several farms. In terms of arable land, the private farmer has around 650 ha, the two agroholdings have 60,000 ha and 250,000 ha respectively, and land belonging to other farms is within the range between 3,000 ha and 12,000 ha. The share of corn in rotations among farms varies from $5 \%$ to $50 \%$ and soybeans from $2 \%$ to $23 \%$. All farmers grow winter wheat, and this crop was used as a reference point as the most important crop regarding the share in the rotation so far.

The questionnaire was constructed in a form to find out the normal expected farming conditions and to eliminate possible biases relating to specific conditions in one year. Therefore, the farmers were asked to indicate answers related not to a particular year, but to the average for the 2011-2013 period. The respondents were asked about the average for the selected timeframe farm gate prices per tonne, yield per ha under standard moisture, and total cost per hectare to calculate the 


\section{Summary of Findings and Conclusions}

economic indicators. It is very important to mention that the selected timeframe is characterized by relatively low fluctuation in the mentioned criteria.

The findings reveal that a rapid acreage expansion of the relatively new crops, such as corn and soy is rooted to monetary reasons rather than to non-monetary ones. The mean profit per hectare for the sample shows that corn brings the highest average return with $609 \mathrm{USD} / \mathrm{ha}$, followed by soybeans with $596 \mathrm{USD} / \mathrm{ha}$ and winter wheat with $423 \mathrm{USD} / \mathrm{ha}$. The profit data has different coefficients of variation: $40.2 \%, 45.7 \%$, and $22.9 \%$ for wheat, corn, and soybeans respectively. They indicate that profit from soybeans is less spread out. The coefficient of standardized skewness for profit distribution is negative for wheat and positive for corn and soybeans. This indicates that the left side tail of the wheat distribution is longer or fatter than that on the right side. The opposite is true for both corn and soybeans.

The cost ratio comparison is also important to understand the farmers' decisions. First, more expenses can be associated with a larger loss in the event of failure. This risk may be mitigated by insurance, which is a commonly used instrument around the world (Vilhelm, 2011). But the market for this service is underdeveloped in Russia: only $17.7 \%$ of the total acreage was insured in 2014 (NAAI, 2015). Second, these expenses demand larger sums of investment that increase the financial burden for farmers, who have been challenged by the severe depreciation of the national currency in 2014.

According to calculation, corn requires more financial input than winter wheat. The difference varies from $10 \%$ to $70 \%$ of the cost per ha. The difference between the total costs of corn and winter wheat can be mainly associated with the higher cost per ha of fertilizers and wheat seeds (this is notable in Russia, where farmers use high-yielding corn hybrids purchased each year and use saved wheat seeds). The total cost of soybeans is not as consistent as that of corn. For half of the respondents, the cost of soybeans surpasses that of winter wheat, while soybeans are cheaper to produce for the other half.

The answers of farmers also revealed the 'soft factors'. The respondents indicated the presence of the necessary infrastructure. The lack of storage facilities was only noted by one farmer out of 15 . The others have enough storage capacities for more than half of the output. For drying, many interviewees invested in special equipment. Among 15 corn growers, 12 have drying equipment, while two farmers expressed their willingness to purchase such equipment soon. The issue regarding transportation can be handled, if needed, with the ample supply of contractors. 


\section{Summary of Findings and Conclusions}

The initial assumption that corn and soy growing can be promoted by politicians was also tested during the interview. The answers show the absence of any administrative levers. Existing subsidies have a very low share in costs and are not allocated to any particular crop, but on the basis of hectares. Therefore, the author assumes the absence of external factors that can distort farmers' decisions regarding crop acreage allocation.

Regarding possible opportunities, further increase of soybeans acreage can be expected as it requires less cost than corn and also provides high returns. Further expansion of corn cultivation can be slowed down by significant cost demands not only for planting, but also for establishing efficient infrastructures with modern storage methods and drying. Agroholdings, agricultural units with sufficient financial resources, will drive corn expansion, but further expansion is unlikely for small-scale farms.

Low-interest rates can also stimulate large investments for new highly profitable crops, but the situation prevailing in the Russian economy did not favour investments during 2014-2015 as the Russian central bank had to keep the interest rate at a high level (CBR, 2015). The situation significantly improved in 2016 and shows some signs of economic recovery (CBR, 2017). However, another factor has begun to play a role: imposition of an export fee for wheat in 2015 (Gov, 2015). Such a fee made wheat planting less attractive, albeit it increased opportunities for further soybeans and corn acreage expansion. Although the fee was cancelled in 2016 (Interfax, 2016), the risk of its re-imposition discounts the price of wheat compared to other tax-free crops.

\subsection{Corn and Soybeans in the Central Black Soil Region of Russia: A fundamental shift in cropping patterns ahead of us?}

As outlined in the introduction, conclusions of the first article are rather ambiguous and cannot distinctly answer the raised questions. Hence, the second article has been published, where two different approaches were applied: a typical farm approach (used by the agri-benchmark network) and the focus group discussion.

The typical farm ${ }^{1}$ approach revealed that the unfavourable weather conditions in 2010 caused much higher economic losses for corn (287 USD/ha) than for wheat (148 USD/ha) due to the high cost and lower market revenue of corn compared to

\footnotetext{
${ }^{1}$ Important to notice that this typical farm cannot be assumed to be fully 'typical' as this farm is part of the agroholding. Although this type is not uncommon in the region, the performance of the farm outstrips the average region levels.
} 


\section{Summary of Findings and Conclusions}

wheat. However, for the other three years in this comparison, the profit per hectare of corn was higher than per hectare of wheat: $234 \mathrm{USD} / \mathrm{ha}$ in 2011, 452 USD/ha in 2012, and $7 \mathrm{USD} / \mathrm{ha}$ in 2013. According to the profit per hectare data, there is a good reason to assume that in recent years, corn showed the trend of being more profitable than wheat; therefore, the economics of agriculture is indeed a key driver of the rapid expansion of corn acreage in the CBSR.

The application of another approach, namely the focus group discussion, was divided into two parts. The aim of the first part was to create an interest for crop economics comparison and to generate a trustful and constructive atmosphere. The second part of the meeting was devoted to the topic of typical production systems for corn, wheat, and soybeans in the Voronezh region. During the course of a joint discussion among participants and the moderator, a spreadsheet with all key cost elements as well as yield and product prices was completed.

The focus group discussion and subsequent calculations revealed that corn generated the highest margin-USD 74 more than wheat. Growing soybeans yields USD 11 more than wheat. A detailed exploration of corn costs reveals that the lion's share of the direct cost is drying cost - this indicates an elevator charge for this service. Given the lack of on-farm drying capacities, this figure represents the current economic conditions for most growers in the region.

However, this picture might change with on-farm investments in drying equipment in the long run. The on-farm drying cost (fuel, depreciation, finance, labour) is estimated at about USD 70 per ha. When using this figure for the calculation, instead of the service fees charged by elevators, the advantage of corn over wheat margin increases to approx. USD 150/ha. Such an increase would most likely strengthen the trend to produce corn. Considering the yield trends for corn vs. wheat in the CBSR, it has to be assumed that the fundamentals will develop in future even more in favour of corn.

Even though theoretical considerations suggest a higher economic risk of producing corn instead of wheat, the growers participating in the focus group discussion were not concerned about this issue. They also did not mention any rotational effects or other non-monetary effects associated with these crops. Whether this means those effects do not exist at all in the CBSR or whether growers participating in the focus group discussion were not yet as sophisticated operators as their colleagues in the West remains to be seen.

Notwithstanding these results, the growers participating in the focus group discussion were not considering strongly expanding their acreage of corn, but they were eager to increase their soybeans acreage. When looking at the increase of 


\section{Summary of Findings and Conclusions}

corn acreage, they were concerned about the associated need for additional investments required for equipment, which was hampered by the high interest rate during the time of the discussion.

Another outcome of this research is the successful approbation of the focus group discussion. It turns out that in principle the globally applied focus group approach did work in Russia. The main barrier to receiving the needed information is the lack of any information-sharing culture and sensitiveness regarding the questions. The focus group discussion designed in this paper allowed the farmers to not reveal sensitive data. An indirect way of expressing information and construction of a typical farm based on a common agreement actually provoked a rich discussion and provided the necessary information.

\subsection{Crop choice decision under uncertainty: A case study in Russia}

Assessment of returns is very important for decision-making, but it ignores the uncertainty that is inevitably linked with the entrepreneurial activity. One peculiar feature of Russians, highlighted by Hofstede (2016), is a high level of uncertainty avoidance. It deals with Russian society's tolerance for ambiguity and indicates to what extent a culture programmes its members to feel either uncomfortable or comfortable in unstructured situations. Uncertainty-avoiding cultures try to minimize the possibility of such situations (Hofstede, 2011). Therefore, cultural aspects may provide a different background, and the involvement of uncertainty in calculations of crop returns may change the results.

A new crop for the CBSR in Russia, such as corn, provides higher returns compared to winter wheat, as outlined in the previous articles, but it may bear additional risk as well. To calculate optimal crop allocations for a different degree of uncertainty avoidance, the author applied two approaches: retrospective and prospective. The retrospective approach only assesses historical data to calculate the optimal crop allocation in the past while assuming that the same pattern will continue in future. In the prospective approach, assumptions about the future are required to calculate the optimal crop portfolio under changing conditions.

In retrospective calculation, the optimal decision for slightly risk-averse farmers would be to distribute the total acreage among sunflower, spring barley, corn, and winter wheat. Producers with the risk-aversion coefficient of 1 and higher would increase the acreage of soybeans and winter wheat; they would decrease the acreage of corn and spring barley until zero in case of extreme risk aversion. Spring wheat is not considered worth growing in any crop portfolio. 


\section{Summary of Findings and Conclusions}

Prospective calculation, unlike retrospective calculations, shows that farmers with relative risk-aversion coefficients within the range of $-0.5-0.5$ would increase winter wheat and sunflower acreages to higher limits to considerably decrease their possible losses. Farmers with higher risk aversion, however, would switch to growing soybeans instead of corn. Crop farmers with the relative risk aversion coefficient equal to 2 and higher would keep winter wheat and sunflower on the higher limits; they would grow soybeans on the residual acreage that can provide the maximum net return of $668 \mathrm{mln}$. roubles and $133 \mathrm{mln}$. roubles of losses with a probability of 0.09 to get a negative net return. Spring wheat and barley should not be grown across all risk-aversion options to reach the optimal portfolio.

Calculation of the optimal crop portfolio, with the example of the agribenchmark typical farm as a case study, shows that farmers with 'normal' levels of risk aversion should grow different crops to diminish risks. Corn, which can be considered as the most profitable crop, can be grown as a monocrop only by risklovers. Slightly risk-averse farmers would diversify production to diminish potential losses. Poor development of insurance services and governmental support force farmers in Russia to use crop portfolio diversification as an uncertainty reduction tool.

High acreage allocation to winter wheat can be explained by its relative stability in terms of crop returns. According to Sizov (2016), the demand for Russian wheat will only increase in the global market, which will stimulate an increase in the acreage of this crop. In 2016 Russia harvested the record high wheat crop-73.3 mln tonnes $(61.8 \mathrm{mln}$ tonnes in 2015) and $119.1 \mathrm{mln}$ tonnes of grains in total (104.8 mln tonnes in 2015) (MCX, 2016). However, the importance of corn and soybeans is not falling, and in 2016 these crops also reached the record highs: 13.8 mln tonnes of corn (13.2 mln tonnes in 2015) and $3.1 \mathrm{mln}$ tonnes of soybeans (2.7 mln tonnes in 2015) (MCX, 2016).

Recent statistics confirm the outcomes of the paper that farmers in Russia, or at least in the CBSR, prefer to diversify their crop portfolios. Therefore, in case of a status quo, a shift to a corn-soybeans rotation or corn as a monocrop, as seen in some parts of the United States (Taheripour et al., 2015), is unlikely. However, a gradual development of the most perspective crops (for instance, winter wheat, soybeans, corn, sunflower) may influence not only the agricultural sector at the regional or country level, but can also influence the global market and trade flows in general. The higher acreage allocation to the previously mentioned crops can be reached by the reduction or elimination of crops having low or no presence in optimal crop portfolios, as calculated in the research (spring wheat and barley). 


\section{Summary of Findings and Conclusions}

\subsection{Welfare analysis of lifting the GM ban in Russia}

A possible application of genetic modification technology can change the Russian agriculture and shift farmers' preferences to well-developed GM products such as corn and soybeans. The outcome of this paper shows that the application of such technology may lead to significant gains for producers. The term 'producer' in this context refers not only to farmers, but also to other counteragents. Lifting the GM ban will lead to a multiplier effect touching all related industries - for example, it will not only affect producers who choose to plant GM seeds, but also conventional growers and seed companies that must decrease the price of conventional seeds to compete with the new product. The same direction of the pricing policy will adhere to trading companies that sell herbicide products for the treatment of conventional varieties.

Lifting the GM ban in Russia may considerably increase the welfare of producers. Consideration of these two GM crops-i.e. corn and soy (assuming a 50\% adoption rate and income benefits of $\$ 30$ and $\$ 50$ for corn and soy, respectively) results in income benefits equal to the current government subsidies for purchasing elite seeds (MCX, 2015). However, additional costs will rise with the necessity of building an infrastructure and separating GM and non-GM products. Any estimation of additional costs related to the GM crop treatment varies and depends on individual countries and accordingly chosen policies applied to the GM products. Such estimation demands careful calculation because the additional costs in the supply chain may cancel out the additional welfare of producers from the cost-saving technology.

The research considers only the direct monetary effects. However, GM crops lead to other benefits as well: the reduced tillage with HT crops leads to fewer machinery costs and release of machines for other operations; the reduction in the amount of crop protection (or change to a less dangerous class of chemicals) leads to environmental and health benefits.

A certain risk for GM technology arises from the growing demand for the so-called 'bio' and non-GM products. For a long time, the USA was a pioneer in the application of GM seeds, but consumers demanded a clear segregation of such products. In 2016 the US President signed a bill about GM labelling and asked the US Department of Agriculture to create a labelling policy (Reuters, 2016). An example of price discount for the GM product can be seen in case of sugar in the US market. Since 2015, cane sugar (non-GM) has increased the spread, which 


\section{Summary of Findings and Conclusions}

almost did not exist before, compared to beet sugar (sugar beets are GM) to 6.25 cents per pound by the end of 2016 (Milling\&Baking news, 2017). This precedent undermines the GM technology and may incline producers to switch back to conventional crops if the price differential continues to grow.

To conclude, this dissertation contributes to the general scientific debate on the prospect of cash crop production in the CBSR of Russia. A robust shift to a cornsoybean rotation or corn as a monocrop is unlikely. However, a gradual expansion of these crops in terms of acreage may influence not only the agricultural sector at the regional or country level, but also global trade flows in general. Application of genetic technologies in Russian agriculture may potentially increase the welfare of producers. However, the additional costs in the supply chain can cancel out the additional welfare for producers and this may be exacerbated by the growing demand for non-GM products. 


\section{Summary of Findings and Conclusions}

\section{References}

CBR (2015) Home page of The Central Bank of the Russian Federation, [Online], Available: http://www.cbr.ru/ [24 June 2015]

CBR (2017) Home page of The Central Bank of the Russian Federation, [Online], Available: http://www.cbr.ru/ [8 January 2017]

Gov (2015) Постановление Правительства России 'Об установлении ставки вывозной таможенной пошлины на пшеницу', [Online], Available: http://government.ru/docs/18291/http://government.ru/docs/18291/ [24 June 2015]

Hofstede, G. (2011). Dimensionalizing Cultures: The Hofstede Model in Context. Online Readings in Psychology and Culture, 2(1). http://dx.doi.org/10.9707/23070919.1014

Hofstede, G. (2016). Country comparison [online] Available through: < https://geert-hofstede.com/russia.html > [Accessed 28 December 2016].

Interfax (2016) Interfax Information Services [Online], Available: http://www.interfax.ru/business/530706 [8 January 2017]

MCX, 2015. Distribution of subsidies in the directions of the state support, Ministry of Agriculture of the Russian Federation, 2015. [Online]. Available: http://www.mcx.ru/documents/document/v7_show/31252..htm [Accessed 26 April 2015].

MCX, 2016. Preliminary estimation of 2016 harvest, Ministry of Agriculture of the Russian Federation, 2016. [Online]. Available: http://www.mcx.ru/documents/document/show/35815.htm [Accessed 28 December 2016].

Milling\&Baking news, 2017. Milling\&Baking news, Sosland Publishing. [Online]. http://www.nxtbook.com/sosland/mbn/2017_01_03/ [Accessed 15 January 2017].

NAAI (2015) International round table of NAAI: agricultural insurance in Russia prepares for a new stage, National Association of Agriculture Insurers [Online], Available: $\mathrm{http} / / / w w w . n a a i . r u /$ eng/press-tsentr/nsa_news/international_ round_table_of_naai_agricultural_insurance_in_russia_prepares_for_a_new_stage/ [23 June 2015] 


\section{Summary of Findings and Conclusions}

Reuters, 2016. U.S. GMO food labeling bill passes Senate, Reuters. [Online]. Available: $\quad$ http://www.reuters.com/article/us-usa-food-gmo-voteidUSKCN0ZO08N [Accessed 8 January 2017].

Sizov, A. Jr. (2016). Russia increases wheat production thanks to growing winter grain area [online] Available through: $<$ https://cereals.ahdb.org.uk $>$ [Accessed 16 December 2016].

Taheripour, F., Fiegel, J., Tyner, W. E. (2015). Development of Corn Stover Biofuel: Impacts on Corn and Soybean Markets and Crop Rotation. Sustainable Agriculture Research, 5(1), 1.

Vilhelm, V. (2011). 'The Role of Public Support of Risk Management in Agriculture', Proceedings of the 20th International Scientific Conference Agrarian perspectives, Prague, pp. 179-186. ISBN 978-80-213-2196-0 